\title{
Non-conservative behaviour of molybdenum in coastal waters: Coupling geochemical, biological, and sedimentological processes
}

\author{
Olaf Dellwig ${ }^{\text {a,c, },}$, Melanie Beck ${ }^{\text {a }}$, Andreas Lemke ${ }^{\text {b }}$, Mirko Lunau ${ }^{\text {b,d }}$, \\ Kerstin Kolditz ${ }^{\text {a }}$, Bernhard Schnetger ${ }^{\text {a }}$, Hans-Jürgen Brumsack ${ }^{\text {a }}$ \\ a Microbiogeochemistry, Institute for Chemistry and Biology of the Marine Environment (ICBM), \\ Carl von Ossietzky University, P.O. Box 2503, D-26111 Oldenburg, Germany \\ ${ }^{\mathrm{b}}$ Biology of Geological Processes-Aquatic Microbial Ecology, Institute for Chemistry and Biology of the Marine Environment (ICBM), \\ Carl von Ossietzky University, P.O. Box 2503, D-26111 Oldenburg, Germany \\ ${ }^{\mathrm{c}}$ Leibniz Institute for Baltic Sea Research IOW, Seestraße 15, D-18119 Rostock, Germany \\ d Alfred-Wegener-Institute for Polar and Marine Research (AWI), Am Handelshafen 12 D-27570 Bremerhaven, Germany
}

Received 10 October 2006; accepted in revised form 23 March 2007; available online 27 March 2007

\begin{abstract}
Non-conservative behaviour of dissolved Mo was observed during specific time periods in the water column of the Wadden Sea of NW Germany. In July 2005 dissolved Mo declined within $36 \mathrm{~h}$ from a level only slightly below seawater ( $82 \mathrm{nM})$ to a minimum value of $30 \mathrm{nM}$, whereas in August 2002 dissolved Mo revealed a tidal cyclicity with maximum values up to $158 \mathrm{nM}$ at low tide. In contrast, cruises in August 2003 and 2004 displayed an almost conservative behaviour of Mo. The decrease in dissolved Mo during July 2005 and elevated values in August 2002 were accompanied by Mo enrichments on aggregates in the water column of the Wadden Sea. Along with Mo, dissolved Mn showed unusual concentration patterns in July 2005, with values distinctly below the common summer level (by a factor of five). A direct relation between the loss of Mo and scavenging by freshly formed $\mathrm{MnO}_{x}$ phases could not be inferred from our data because both metals revealed inverse patterns. Parallel to decreasing dissolved Mo concentrations dissolved Mn showed an increasing trend while particulate Mn decreased. Such finding is compatible with the formation of oxygen-depleted zones in aggregates, which provide suitable conditions for the rapid fixation of Mo and parallel release of Mn by chemically and/or microbially mediated processes. Our assumption is supported by biological (e.g. number of aggregate-associated bacteria) and sedimentological (e.g. aggregate abundance and size) parameters. The production of organic components (e.g. TEP) during breakdown of an algae bloom in July 2005 led to the formation of larger Mo-enriched aggregates, thus depleting the water column in dissolved Mo. After deposition on and incorporation into sandy tidal flats these aggregates are rapidly decomposed by microbial activity. Pore water profiles document that during microbial decomposition of these aggregates, substantial amounts of Mo are released and may replenish and even enrich Mo in the open water column. We postulate a conceptual model for the observed non-conservative behaviour of Mo in coastal waters, which is based on the tight coupling of geochemical, biological, and sedimentological processes. (c) 2007 Elsevier Ltd. All rights reserved.
\end{abstract}

\section{INTRODUCTION}

Molybdenum is an essential trace metal for planktonic organisms, e.g. cyanobacteria, as it plays an important role

\footnotetext{
* Corresponding author. Fax: +4903815197352.

E-mail address: olaf.dellwig@io-warnemuende.de (O. Dellwig).
}

in nitrogen metabolism. Mo forms a cofactor for various nitrogen-fixation and nitrate reductase systems (e.g. Fogg and Wolfe, 1954; Fogg, 1962; Robson et al., 1986; Mendel, 2005). Despite its biological requirement, Mo is the most abundant trace metal in ocean water (about $107 \mathrm{nM}$ ) and generally displays a conservative behaviour unaffected by biological activity (Collier, 1985; Morris, 1975). However, Berrang and Grill (1974) found variable Mo concentrations 
in coastal waters of Saanich Inlet ranging from 73 to $107 \mathrm{nM}$. The authors suggested a non-biotic coupling to Mn oxidation and subsequent scavenging by freshly formed $\mathrm{MnO}_{x}$ phases. Adelson et al. (2001) also ascribed importance to Mn cycling on Mo behaviour. They proposed a model for the removal of $\mathrm{MoO}_{4}{ }^{2-}$ from surface waters and its pre-concentration at the sediment/water interface by settling $\mathrm{Mn}(\mathrm{Mo}) \mathrm{O}_{x}$ phases. A special feature of this model is that $\mathrm{MoO}_{4}{ }^{2-}$ is not necessarily reduced during transfer to the sediment. Moreover, $\mathrm{MoO}_{4}{ }^{2-}$ is released at the sediment/water interface from where it may diffuse back into the water column and/or into the sediment. Within the sediment $\mathrm{MoO}_{4}{ }^{2-}$ can be fixed by thiol or covalent bondings to transition metals followed by reduction and final burial as sulphide, which leads to typical Mo enrichments frequently observed in TOC-rich marine sediments (e.g. Brumsack, 2006).

In contrast, Head and Burton (1970) observed decreasing Mo concentration in the estuary of Southampton Water during spring, which they attributed to its utilisation by plankton and/or complexing by organic particles. Yamazaki and Gohda (1990) also observed Mo depletion in coastal waters (Seto Inland Sea, North Pacific, minimum $69 \mathrm{nM}$ ), which was explained by scavenging of Mo as an organically associated species; a relationship, which was suggested earlier by Szalay and Szilagyi (1967) and Brumsack and Gieskes (1983). More recently, Tuit and Ravizza (2003) reported both, positive and negative Mo concentration anomalies in a region of nitrogen-fixation in the Eastern Equatorial Pacific $(+5 \mathrm{nM},-3 \mathrm{nM})$, which presumably are related to biological processes. A coupling of Mo anomalies to Mn was not observed by these authors. Recent publications by Engel et al. (2004) and Lunau et al. (2006a) emphasise the importance of organic macromolecules produced during algae blooms on particle dynamics in the water column. These compounds are supposed to maintain aggregate formation in the water column, which possibly also influences the cycles of trace metals via scavenging by organic matter or reduction in the suboxic interior of larger particles. Evidence for the existence of oxygendepleted zones is provided by studies of Alldrege and Cohen (1987) who demonstrated substantial oxygen depletion in marine snow. In addition, Ploug et al., 1997 measured microscale distributions of oxygen in laboratory-made aggregates and concluded that anoxic conditions can prevail for a few hours. Stable anoxic conditions, however, would require a high and continuous carbon supply.

In this contribution we present data, which show distinct non-conservative behaviour of Mo (positive and negative anomalies) in coastal waters of the Southern North Sea during time-periods associated with changes in productivity. These data were obtained during several ship cruises in the backbarrier tidal flat of Spiekeroog Island and the adjoining near-coastal German Bight between 2002 and 2005 (Fig. 1a and b). Along with Mo, we present Mn data, which also reflect a much more complex seasonal variability as assumed so far (e.g. Dellwig et al., 2007). Earlier investigations suggested a simple seasonal behaviour of $\mathrm{Mn}$, with concentrations of dissolved $\mathrm{Mn}$ increasing from winter to summer by a factor of about 10 due to elevated release from the tidal flat sediments. In contrast, data from 2005 point towards a distinctly higher variability of Mn during summer which seems to be controlled by internal recycling processes in the Wadden Sea system. Thus, the major goal of this paper is to provide possible explanations for the observed unusual behaviour of both metals. Previous work in the study area has shown that Mn-oxidation forms a prominent process in the Wadden Sea (Dellwig et al., 2007), which can influence the patterns of other trace metals like Mo via scavenging. However, we strongly focus on the influence of microbial and sedimentological processes on the geochemistry of Mo and Mn, and postulate a tight coupling between these processes.

\section{GEOGRAPHICAL SETTING}

The Wadden Sea of the Southern North Sea with its tidal flats and barrier Islands has formed about $7500 \mathrm{BP}$ as a result of the Holocene sea-level rise (Streif, 1990). Today, the morphology of the coastline, which stretches about $500 \mathrm{~km}$ from Den Helder in the Netherlands to Esbjerg in Denmark, is largely determined by human activities (e.g. dike building). The East-Frisian Wadden Sea, which represents about $15 \%$ of the entire Wadden Sea, forms our major study area. It is characterised by mesotidal conditions (tidal range $2.2-2.8 \mathrm{~m}$ ).

Fig. 1a shows the sampling locations during the cruises in the German Bight and the adjacent backbarrier tidal flats. This contribution is based on data from the following cruises: RV Heincke 220 (October 2004), RV Heincke 234 (July 2005), RV Senckenberg (January 2004, 2005; February 2002, 2003; April 2003, 2005; May 2002; July 2005; August 2002, 2003; November 2002-2005). Further sampling was done on a time-series station in the tidal inlet of Spiekeroog Island in August, September, and October 2005.

Sampling was performed in intervals of 10-30 min during transects (RV Heincke 220: $54^{\circ} 29.94^{\prime} \mathrm{N} / 7^{\circ} 19.92^{\prime} \mathrm{E}$ to $53^{\circ} 47.92^{\prime} \mathrm{N} / 7^{\circ} 32.79^{\prime} \mathrm{E}$ and $234: 53^{\circ} 48.04^{\prime} \mathrm{N} / 7^{\circ} 30.62^{\prime} \mathrm{E}$ to $54^{\circ} 06.09^{\prime} \mathrm{N} / 745.47^{\prime} \mathrm{E}$ ) and every $30 \mathrm{~min}$ during time-series in 2002-2004 (RV Senckenberg). In 2005 sampling intervals were raised to $60 \mathrm{~min}$. While samples between 2002 and 2004 originate exclusively from surface waters, sampling on RV Senckenberg in 2005 was done almost simultaneously at three depth intervals.

Fig. 1. (a) Map of the study area showing the sampling sites during several cruises in the Wadden Sea of NW Germany. The square denotes the main study area in the backbarrier tidal flats of the Islands of Spiekeroog and Langeoog. (b) detailed map of the backbarrier areas of the Islands of Spiekeroog and Langeoog showing the time-series locations in the tidal inlets (Otzumer Balje, OB 1; Accumer Ee, AE), at the $10 \mathrm{~m}$ depth line (OB2), and in the central backbarrier area (CBA). The asterisks mark the locations of the pore water sampling sites on the Janssand tidal flat. The black square indicates the location of sediment traps at the transition zone of tidal flats and salt marshes of Langeoog Island. The light grey areas indicate tidal flats emerging at low tide. 


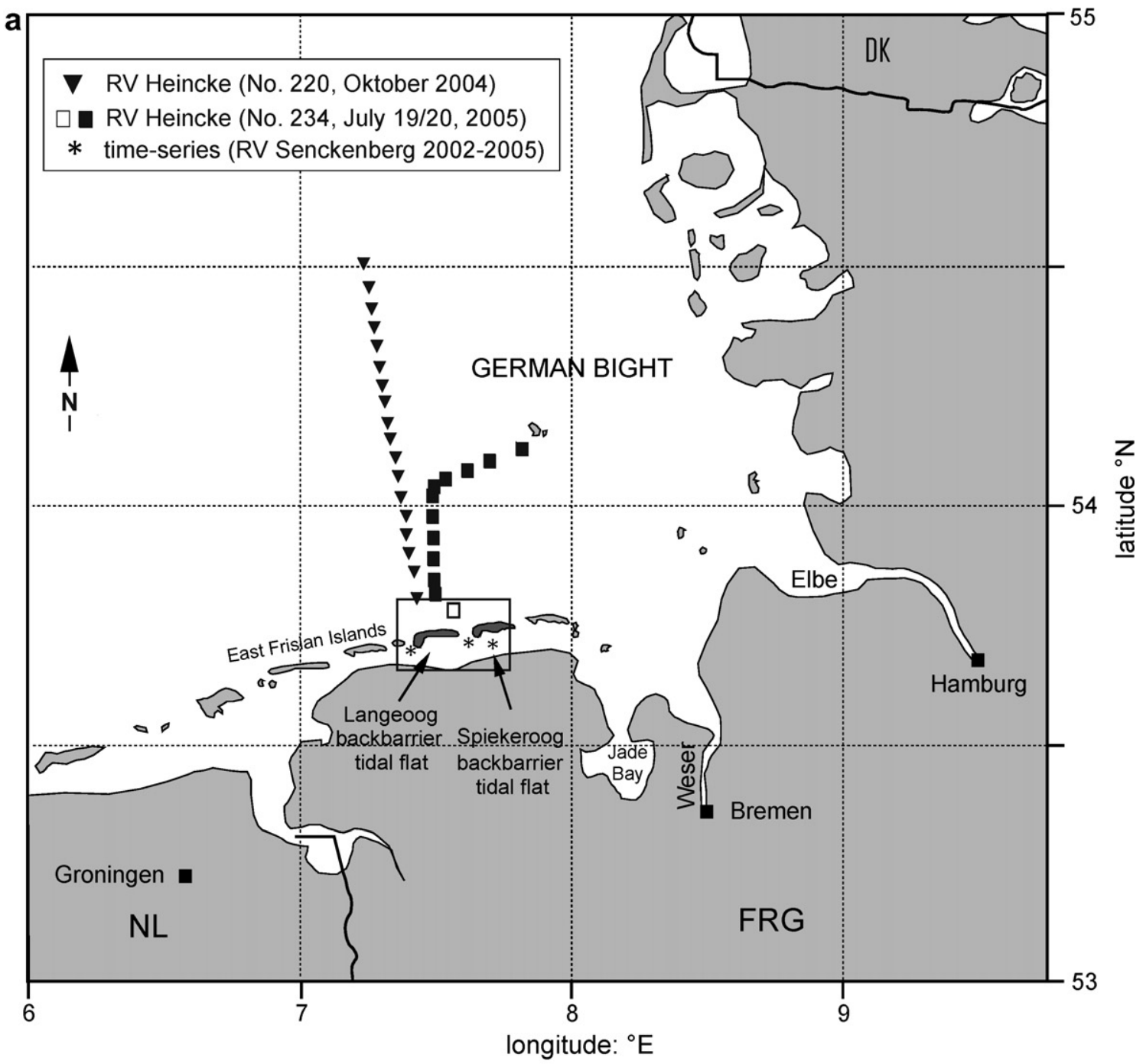

b

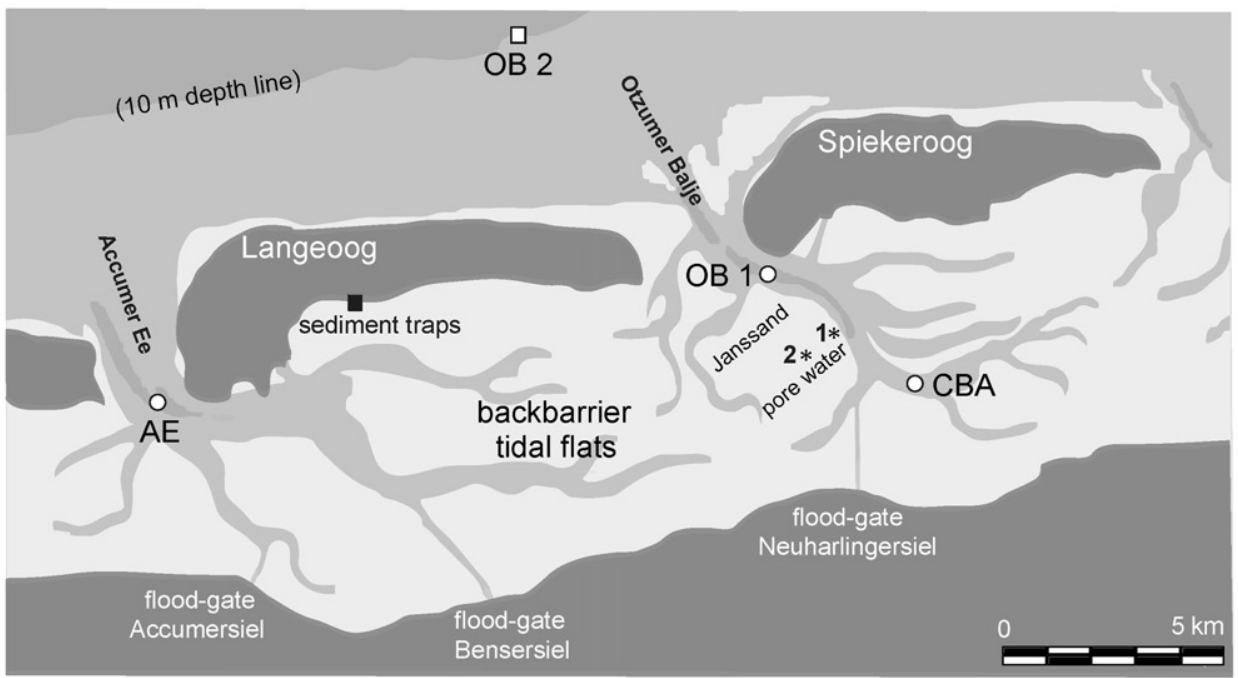


Fig. 1b shows our main study area in the backbarrier tidal flats of the Islands of Spiekeroog and Langeoog. The locations OB1 in the tidal inlet of Spiekeroog Island (Otzumer Balje; $53^{\circ} 44.87^{\prime} \mathrm{N} / 7^{\circ} 40.29^{\prime} \mathrm{E}$ ) and CBA (central backbarrier area; $53^{\circ} 43.43^{\prime} \mathrm{N} / 7^{\circ} 43.32^{\prime} \mathrm{E}$ ) mark the sampling campaigns with RV Senckenberg. OB2 $\left(53^{\circ} 48.21^{\prime} \mathrm{N} /\right.$ $\left.7^{\circ} 26.95^{\prime} \mathrm{E}\right)$ is positioned at the $10 \mathrm{~m}$-depth line where sampling was performed during one cruise with RV Heincke in July 2005. Additionally, a sampling campaign was carried out in the tidal inlet of Langeoog Island at position AE in July 2005 (Accumer Ee; 53 $43.53^{\prime} \mathrm{N} / 7^{\circ} 26.95^{\prime} \mathrm{E}$ ). In the transition zone between tidal flats and salt marshes of the Island of Langeoog $\left(53^{\circ} 44.77^{\prime} \mathrm{N} / 7^{\circ} 31.46^{\prime} \mathrm{E}\right.$ samples from sediment traps were taken monthly between March and November 2005).

The light grey areas in Fig. $1 \mathrm{~b}$ indicate tidal flats emerging at low tide. The Janssand is one of the flats in the backbarrier area of Spiekeroog Island. In this area sandy sediments predominate, however at depths exceeding $3 \mathrm{~m}$ these are intermingled with silt-clay layers. Pore water samples were taken at two locations on this flat (asterisks in Fig. 1b). Location 1 is situated very close to the main tidal channel of the backbarrier area of Spiekeroog Island $\left(53^{\circ} 44.183^{\prime} \mathrm{N}\right.$, $007^{\circ} 41.904^{\prime} \mathrm{E}$ ), whereas location 2 is positioned further towards the centre of the sand flat $\left(53^{\circ} 43.96^{\prime} \mathrm{N} / 7^{\circ} 41.28^{\prime} \mathrm{E}\right)$. Pore waters were retrieved in situ from the sediment using permanently installed samplers. The construction and the use of these samplers are described in more detail by Beck et al. (accepted for publication).

\section{MATERIALS AND METHODS}

\subsection{Geochemistry}

\subsection{1. $\mathrm{Mo}, \mathrm{Mn}, \mathrm{Al}$}

Depending on SPM contents, $0.25-1.51$ of seawater were filtered through pre-weighed Millipore Isopore membrane filters $(0.4 \mu \mathrm{m}$ polycarbonate $\mathrm{PC})$ for multi-element analyses. Filters were rinsed with $60 \mathrm{ml}$ purified water, dried at $60{ }^{\circ} \mathrm{C}$ for $48 \mathrm{~h}$ and re-weighed for the determination of total SPM. Samples for analysis of dissolved metals in seawater and pore water were taken with pre-cleaned PE-syringes and $0.45 \mu \mathrm{m}$ SFCA syringe filters. These samples were acidified to $1 \mathrm{vol} \% \mathrm{HNO}_{3}$ (conc.) in pre-cleaned PE-bottles.

For multi-element analysis the PC filters were treated overnight with $1 \mathrm{ml} \mathrm{HNO}_{3}$ and $2 \mathrm{ml} \mathrm{HClO}_{4}$ in closed PTFE autoclaves (PDS-6; Heinrichs et al., 1986) at room temperature to oxidise organic matter. Then the filters were decomposed at $160^{\circ} \mathrm{C}$. SPM residues were digested in the same PTFE vessels at $180^{\circ} \mathrm{C}$ after adding a mixture of $1 \mathrm{ml}$ concentrated $\mathrm{HClO}_{4}$ and $3 \mathrm{ml}$ concentrated $\mathrm{HF}$. After digestion acids were evaporated at $180{ }^{\circ} \mathrm{C}$, residues were redissolved and fumed off three times with $2 \mathrm{ml}$ semi-concentrated $\mathrm{HCl}$ and diluted with $2 \mathrm{vol} \% \mathrm{HNO}_{3}$ to a final dilution of 2500 or 5000 . All acids were pre-cleaned by sub-boiling distillation, except for HF (suprapure quality). Material from sediment traps was sieved and the $<63 \mu \mathrm{m}$ fraction was digested with $\mathrm{HClO}_{4}$ and $\mathrm{HF}$.

Particulate Al and Mn were analysed by ICP-OES (Perkin Elmer Optima 3000XL), whereas particulate Mo as well as dissolved Mn and Mo were measured by ICP-MS (Thermo Finnigan MAT ELEMENT). Dissolved trace metals were determined directly from 25-fold diluted samples. The analytical procedure applied is similar to the method published by Rodushkin and Ruth (1997). Data presented here are based on measurements of Mo98 in low resolution and Mn55 in medium resolution with Y89 and Cs133 as internal standards, respectively. As we measured Mo98 instead of Mo95, the interference of $\mathrm{BrO}$ was negligible. However, Mo showed significant memory effects within the sample introducing system (e.g. tubings, nebuliser), which required sufficient wash and take up times (60 $90 \mathrm{~s}$ ). Contamination effects were excluded by measurement of filter and onboard procedural blanks. As filters for the analysis of particulate $\mathrm{Mn}$ and Mo were thoroughly rinsed with purified water any corrections for residual salt were unnecessary. This is also supported by measurement of particulate $\mathrm{Na}$, which only reflected the normal detrital background level.

Precision $(1 \sigma)$ and accuracy of all measurements were checked by parallel analysis of international and in-house reference materials. GSD-4 and our in-house shale standard TW-TUC were used as a reference for particulate samples (Al: precision $2.2 \%$, accuracy $-0.6 \%$; Mn: $1.5 \%,-0.9 \%$; Mo: $9.0 \%,-2.1 \%$ ), whereas reference seawater standards CASS-3 and CASS-4 (Canada) were used for dissolved samples (Mn: 6.1\%, 6.7\%; Mo: 2.6\%, 1.8\%). For the analysis of $\mathrm{Mn}$ in pore water, a spike solution was added to these reference standards as the concentration for Mn was much higher in the Wadden Sea pore waters than in the original reference materials. The final $\mathrm{Mn}$ concentration in the reference standards was $3640 \mathrm{nM}$.

\subsubsection{Particulate organic carbon (POC) and total particulate nitrogen (TPN)}

Subsamples of $100 \mathrm{ml}$ were filtered onto precombusted and preweighed $\mathrm{GF} / \mathrm{F}$ filters (Whatman, $25 \mathrm{~mm}$ diameter), rinsed with $2-5 \mathrm{ml}$ of distilled water to remove salt and kept frozen at $-20{ }^{\circ} \mathrm{C}$ until further analysis. Prior to analysis the filters were exposed to the fume of concentrated hydrochloric acid for $12 \mathrm{~h}$ to remove carbonates. Thereafter, filters were transferred into tin capsules (IVA, Meerbusch, Germany) and analysed for POC and TPN by a FlashEA $1112 \mathrm{CHN}$-analyser (Thermo Finnigan). Analysis was done at a combustion temperature of $1000^{\circ} \mathrm{C}$ and a column temperature of $35^{\circ} \mathrm{C}$. Concentrations were calculated by an external calibration curve with methionin $(0.1-2.5 \mathrm{mg})$.

\subsubsection{Chlorophyll-a and phaeopigments}

Subsamples of $500 \mathrm{ml}$ were filtered onto GF/F filters (Whatman, $47 \mathrm{~mm}$ diameter), immediately wrapped into aluminum foil and kept frozen at $-20^{\circ} \mathrm{C}$ until further analysis in the shaded lab within one week. Filters were mechanically hackled and extracted in hot ethanol $\left(75^{\circ} \mathrm{C}\right)$ for $1 \mathrm{~h}$ in the dark. Concentrations of chlorophyll- $a$ and phaeopigments were determined spectrophotometrically and calculated following the procedure described by von Tuempling and Friedrich (1999). Chlorophyll total was calculated as the sum of chlorophyll- $a$ and phaeopigments. 


\subsubsection{Dissolved organic carbon}

The measurements of dissolved organic carbon (DOC) were performed on GF/F-filtrates by combustion and IRdetection with a multi N/C 3000 analyser (Analytik Jena). The filtrate was stored in brown glass bottles and acidified with semi-concentrated $\mathrm{HCl}(500 \mu \mathrm{l}$ per $100 \mathrm{ml})$. The analysis was checked by measurements of K-hydrogenphthalate solutions containing 2 and $3 \mathrm{mg}^{-1} \mathrm{C}$ (precision $4.6 \%$; accuracy $-0.4 \%)$.

\subsection{Sedimentology}

\subsubsection{Documentation of aggregate abundance and size}

Photos were taken with an in situ camera device. Samples were illuminated by a red light diode laser $(\lambda=658 \mathrm{~nm}$, $50 \mathrm{~mW}$ ), and the abundance and size distribution of the aggregates were documented by digital photography using a Sony Cybershot DSC-F828. The resolution of the DSCF828 is $15 \mu \mathrm{m}$ per pixel. Further data processing and image analysis was done in the lab using the software package analySIS V 3.0 (Soft Imaging System, Münster, Germany). We determined abundance, size distribution, equivalent circular diameter (ECD), and surface area of the aggregates. For further details of data analysis see Lunau et al. (2004).

\subsubsection{Suspended particulate matter (SPM)}

Subsamples of $500-1000 \mathrm{ml}$ were filtered onto precombusted $\left(2 \mathrm{~h}, 450{ }^{\circ} \mathrm{C}\right)$ and preweighed $\mathrm{GF} / \mathrm{F}$ filters (Whatman, $47 \mathrm{~mm}$ diameter). Filters were rinsed with 10 $20 \mathrm{ml}$ of distilled water to remove salt and kept frozen at $-20^{\circ} \mathrm{C}$ until further analysis in the lab within one week. After drying for $12 \mathrm{~h}$ at $60{ }^{\circ} \mathrm{C}$, filters were adapted to room temperature for $30 \mathrm{~min}$ and weighed again. SPM was calculated as the difference between filter weight before and after sample filtration and normalised per liter.

\subsection{Microbiology}

\subsubsection{Bacterial cell counts}

Subsamples were transferred into $5 \mathrm{ml}$ cryotubes (Nunc) onboard ship, preserved with $2 \%$ (final concentration) glutardialdehyde (resp. 1\%/0.05\% PFA/GDA mixture in April
2005) and stored at $-20^{\circ} \mathrm{C}$ until further processing. Abundances of total and free-living bacteria (FL) were enumerated by epifluorescence microscopy after staining with SybrGreen I, applying a new detachment procedure. In brief: for the determination of the free living bacteria cells were washed with $3-5 \mathrm{ml}$ of a TAE-methanol mix (1:1, $\mathrm{pH}$ 7.4) before the filters were transferred to a microscope slide and stained by SybrGreen I mixed into the mounting solution (1:40) containing moviol 4-88 (polyvinylalcohol 4-88). For the determination of total bacteria samples were treated with $10-30 \%$ methanol $\left(35^{\circ} \mathrm{C}\right)$ and ultrasonicated before centrifugation. The number of aggregate-associated bacteria (AGG) was calculated as the difference of total bacteria and FL bacteria. This procedure is particularly suitable for samples with high loads of SPM and results in a very efficient detachment of AGG bacteria, yielding reliable numbers of the latter with a standard error of $<15 \%$. For further details of the method see Lunau et al. (2006b).

Stained cells were counted with a Zeiss Axiolab 2 microscope at $1000 \times$ magnification by using a $100 \times$ Plan-Apochromat oil-immersion objective (lamp: HBO 50, filter set: Zeiss, Ex 450-490, FT 510, LP 515). The filtered sample volume yielded $60-150$ stained cells in the counting grid. For each sample 10 grids and a minimum of 600 cells per filter were enumerated.

\subsection{CTD}

CTD data were determined with a CTD probing system (Model OTS 1500, ME Meerestechnik-Elektronik, Germany) equipped with sensors for measuring pressure, conductivity and temperature. Salinity and density were calculated according to UNESCO standards (UNESCO, 1981).

\section{RESULTS}

\subsection{Biological properties}

The data presented in Table 1 provide an overview about several biological parameters in surface samples from

Table 1

Average surface values and ranges (in parentheses) of several biological, meteorological, and sedimentological parameters for the Wadden Sea of Spiekeroog Island (tidal inlet OB1 and central backbarrier area CBA)

\begin{tabular}{|c|c|c|c|c|}
\hline & $\begin{array}{l}\text { Wadden Sea } \\
\text { January } 2005\end{array}$ & $\begin{array}{l}\text { Wadden Sea } \\
\text { April } 2005\end{array}$ & $\begin{array}{l}\text { Wadden Sea } \\
\text { July } 2005\end{array}$ & $\begin{array}{l}\text { Wadden Sea } \\
\text { November } 2005\end{array}$ \\
\hline Chlorophyll- $a\left(\mu \mathrm{g}^{-1}\right)$ & $2.3(1.2-3.3)$ & $4.8(3.2-6.4)$ & $5.0(3.1-6.7)$ & $2.2(0.6-3.2)$ \\
\hline Phaeopigments $\left(\mu \mathrm{g}^{-1}\right)$ & $6.0(2.9-9.6)$ & $1.6(0.6-2.0)$ & $3.1(0.3-5.12)$ & $5.8(1.7-8.8)$ \\
\hline Phaeopigments/chlorophyll $1_{\text {total }}(\%)$ & 64 & 25 & 38 & 73 \\
\hline $\mathrm{DOC}(\mathrm{mM})$ & $0.20(0.17-0.24)$ & $0.19(0.15-0.24)$ & $0.25(0.2-0.32)$ & $0.28(0.22-0.44)$ \\
\hline $\operatorname{POC}(\%)$ & $3.4(2.5-5.0)$ & $7.1(2.9-16.3)$ & $7.6(1.1-28.7)$ & $2.4(0.5-4.5)$ \\
\hline Free-living bacteria $(\mathrm{FL})\left[\right.$ cells $\left.\times 10^{6} \mathrm{ml}^{-1}\right]$ & $1.1(0.6-1.4)$ & $0.7(0.4-1.2)$ & $1.7(1.0-2.3)$ & $1.6(1.4-1.8)$ \\
\hline Aggregate-associated bacteria (AGG) $\left[\right.$ cells $\times 10^{6} \mathrm{ml}^{-1}$ ] & $0.7(0.2-1.0)$ & $0.7(0.2-1.9)$ & $1.3(0.3-3.2)$ & $1.6(1.1-2.2)$ \\
\hline Av. wind speed $\left(\mathrm{m} \mathrm{s}^{-1}\right)$ & 11.2 & 3.7 & 12.5 & 4.6 \\
\hline Av. wind direction $\left({ }^{\circ}\right)$ & 230 & 171 & 265 & 216 \\
\hline $\mathrm{SPM}\left(\mathrm{mg}^{-1}\right)$ & $72(29-128)$ & $8(2-18)$ & $22(6-66)$ & $52(21-95)$ \\
\hline Aggregate number (AGA) $\left[\mathrm{ml}^{-1}\right]$ & $500(60-2400)^{\mathrm{a}}$ & - & $280(110-420)$ & - \\
\hline Aggregate size $(\mathrm{ECD})[\mu \mathrm{m}]$ & $88(64-110)^{\mathrm{a}}$ & - & $118(91-139)$ & - \\
\hline
\end{tabular}

\footnotetext{
${ }^{a}$ Data from 2003 (Lunau et al., 2006a,b).
} 
the Wadden Sea cruises in 2005. These data were obtained from surface samples. Concentrations of chlorophyll- $a$ increase roughly by a factor of two from January to April and July and decrease again towards November. This finding is consistent with the occurrence of spring and summer algae blooms, whereas the generally less pronounced autumn bloom is not covered by our cruises. The percentage of phaeopigments from total chlorophyll designates the quality of the algae material and provides information about the state of the bloom. The percentage shows highest values during January and November when resuspension of formerly deposited algal detritus is highest. In contrast April and July values are distinctly lower as both cruises cover algae blooms and indicate fresh algal material. However, the percentage of July is higher when compared with April, which may be indicative for a final stage of the bloom. A further difference during the algae blooms in April and July 2005 is seen in DOC data, which are higher in July due to release of organic compounds during the breakdown of the bloom (Table 1). The occurrence of algae blooms also leads to elevated organic matter contents of particles as seen in POC values during April and July.

Additionally, Table 1 presents the number of free-living bacteria (FL) and aggregate-associated bacteria (AGG) in surface water of the Wadden Sea for the cruises in 2005. Interestingly, the number of FL and AGG bacteria is comparable in January and April, which may be due to pronounced resuspension in January. In contrast, the number of FL and AGG bacteria is distinctly higher in July when compared with the previous cruises, which implies elevated microbial activity in the water column during summer. Unusually high numbers are seen in November, which is most likely caused by remnants of prior blooms and resuspension.

\subsection{Sedimentological properties}

Average surface values of SPM concentrations for the cruises in 2005 are given in Table 1. Generally, maximum SPM concentrations coincide with maximum current velocities, particularly in surface samples. In addition, wind speed and direction are important factors controlling the SPM load of the water column. Similar values for both parameters are seen during the cruises in January and July 2005. Highest concentrations of SPM are observed in January while in April data are considerably lower and amount to only $10-20 \%$ of the winter values. From July towards November SPM values increase again. Distinctive features in July 2005 are differences for the three sampling depths, which are less pronounced in January 2005 (Fig. 2). Especially the SPM concentrations of the bottom samples are remarkably high when compared with the surface values. In addition, the difference between both locations in the tidal inlet (OB1) and the central part of the tidal basin (CBA) is more pronounced in July 2005.

Furthermore aggregate properties differ between winter and summer times (Table 1). Even if we cannot provide data for the winter of 2005, a statistical comparison of February 2003 (Lunau et al., 2006a) with July 2005 (this study) showed significant differences in aggregate numbers
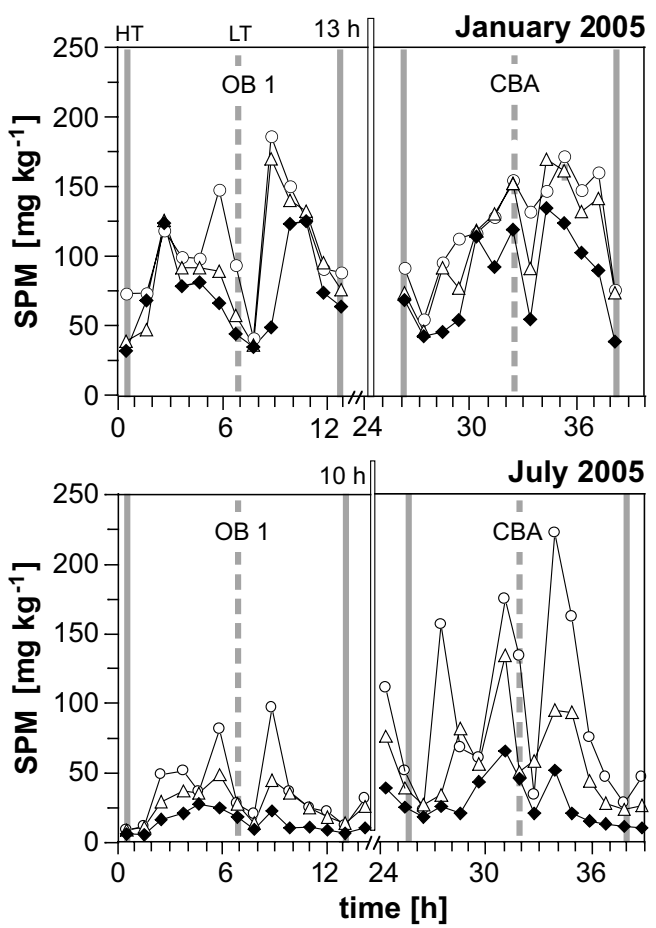

Fig. 2. Tidal patterns of suspended particulate matter (SPM) for the Wadden Sea cruises in January and July 2005 (Spiekeroog Island). The vertical grey and dashed lines denote high tide (HT) and low tide (LT). The vertical rectangle marks a time gap between the sampling campaigns. Please note that wind speed and direction are comparable during both cruises (Table 1).

(Mann-Whitney Test, $P=0.026)$ and size ( $t$-Test, $P=0.002)$. Mean aggregate abundance over a tidal cycle was almost twice as high in February compared to July $\left(500 \mathrm{ml}^{-1}\right.$ vs. $\left.280 \mathrm{ml}^{-1}\right)$, while aggregate size revealed distinctly higher values during the growing season (ECD: $118 \mu \mathrm{m}$ in July vs. $88 \mu \mathrm{m}$ in February).

\subsection{Mo and Mn in the water column of the wadden sea}

\subsubsection{Molybdenum}

Table 2 presents concentrations of dissolved Mo $\left(\mathrm{Mo}_{\text {diss }}\right)$ in the backbarrier tidal flat of Spiekeroog Island (tidal inlet Otzumer Balje OB1; central backbarrier area CBA) for the cruises in January, April, July, and November 2005. Values of $\mathrm{Mo}_{\text {diss }}$ normalised to a salinity of 33.7 (offshore value from October 2004) are shown as well. During the cruises in January, April, and November salinity normalised $\mathrm{Mo}_{\text {diss }}$ shows the expected conservative behaviour. Values are essentially identical to the offshore concentration, which was determined on samples from a cruise in October $2004\left(54^{\circ} 30,7^{\circ} 20\right.$ to $\left.54^{\circ} 20,7^{\circ} 23\right)$ during a period of low biological activity. Previous Wadden Sea cruises in winter, spring, and autumn 2002 to 2004 confirm this conservative behaviour (not shown) with normalised values similar or slightly above the offshore value.

Non-conservative behaviour of $\mathrm{Mo}_{\text {diss }}$ was observed in July 2005 with values distinctly below the seawater level. Based on almost identical salinities during that time interval 
Table 2

Average surface values and ranges (in parentheses) of water temperature, salinity as well as dissolved and particulate geochemical parameters for the Wadden Sea (tidal inlet OB1 and central backbarrier area CBA) and the German Bight

\begin{tabular}{llllll}
\hline & $\begin{array}{l}\text { Wadden Sea } \\
\text { January 2005 }\end{array}$ & $\begin{array}{l}\text { Wadden Sea } \\
\text { April 2005 }\end{array}$ & $\begin{array}{l}\text { Wadden Sea } \\
\text { July 2005 }\end{array}$ & $\begin{array}{l}\text { Wadden Sea } \\
\text { November 2005 }\end{array}$ & $\begin{array}{l}\text { German Bight offshore } \\
\text { October 2004 }\end{array}$ \\
\hline Temperature $\left({ }^{\circ} \mathrm{C}\right)$ & $7.1(6.5-7.4)$ & $10.1(8.8-12.2)$ & $19.3(18.6-20.1)$ & $8.9(7.4-9.8)$ & $15.7(15.6-15.8)$ \\
Salinity $(\mathrm{psu})$ & $31.1(29.7-32.0)$ & $32.4(32.1-32.6)$ & $31.9(31.5-32.1)$ & $29.9(29.3-30.3)$ & $33.7(33.6-33.8)$ \\
$\mathrm{Mo}_{\text {diss }}(\mathrm{nM})$ & $95(90-101)$ & $99(95-101)$ & $57(30-82)$ & $91(87-94)$ & $103(100-105)$ \\
$\mathrm{Mo}_{\text {diss,33.7psu }}(\mathrm{nM})$ & $103(98-107)$ & $102(97-105)$ & $60(32-86-30)$ & $103(98-108)$ & \\
$\mathrm{Mo}_{\text {part }}\left(\mathrm{mg} \mathrm{kg}{ }^{-1}\right)$ & $1.3(1.1-1.5)$ & $2.0(1.2-3.6)$ & $15.3(3.8-39.6)$ & $3.3(1.9-4.2)$ & $2.0(0.7-3.2)$ \\
$\mathrm{Mn}_{\text {diss }}(\mathrm{nM})$ & $48(20-113)$ & $331(121-679)$ & $135(51-256)$ & $65(36-125)$ & $12(9-20)$ \\
$\mathrm{Mn}_{\text {part }}\left(\mathrm{mg} \mathrm{kg}{ }^{-1}\right)$ & $714(653-754)$ & $461(178-703)$ & $1205(803-1636)$ & $875(678-1045)$ & $1020(996-1039)$ \\
$\mathrm{Al}_{\text {part }}(\%)$ & $5.7(5.4-6.1)$ & $4.1(1.8-5.8)$ & $5.3(4.5-5.9)$ & $5.8(5.0-6.4)$ & $4.1(3.8-4.6)$ \\
\hline
\end{tabular}

$\mathrm{Mo}_{\text {diss,33.7psu }}$ indicates values normalized to offshore salinity.

(Table 2), a noticeable influence of fresh water via the floodgate in Neuharlingersiel can be excluded (compare Fig. 1b). The tidal pattern of $\mathrm{Mo}_{\text {diss }}$ in July 2005 is visualised in Fig. 3a. As salinity variations were comparatively small and close to the offshore value during these cruises, we present only absolute concentrations in Fig. 3. At the beginning of the cruise in July $2005 \mathrm{Mo}_{\text {diss }}$ displays a value of $82 \mathrm{nM}$ and within the following $36 \mathrm{~h}$ its concentration decreases dramatically to a minimum value of $30 \mathrm{nM}$, which is less than one third of the seawater value. This rapid loss in $\mathrm{Mo}_{\text {diss }}$ is seen in the entire water column as indicated by the similar patterns of the three depth intervals investigated (surface, middle app. $7 \mathrm{~m}$ above seafloor, and bottom app. $1.5 \mathrm{~m}$ above seafloor) and seems to be independent of the tidal exchange, i.e., input of Mo-rich seawater during high tide. Furthermore, this phenomenon spans the whole tidal basin because data from both, the tidal inlet (OB1) and the central part of the backbarrier tidal flat (CBA) show the same trend of decreasing $\mathrm{Mo}_{\text {diss }}$ concentrations. The rate of $\mathrm{Mo}_{\text {diss }}$ loss is about $2 \mathrm{nM} \mathrm{h}^{-1}$ at location OB1 and $1.5 \mathrm{nM} \mathrm{h}^{-1}$ at $\mathrm{CBA}$, with a more pronounced linearity of Mo loss in the tidal inlet (OB1: $r=0.89$; CBA: $r=0.69$ ).

The decreases in $\mathrm{Mo}_{\text {diss }}$ were also observed in July 2005 during parallel sampling at position OB2 off Spiekeroog Island at the $10 \mathrm{~m}$ depth line and in the western backbarrier tidal flat of Langeoog Island (AE) where sampling started about $14 \mathrm{~h}$ prior to the campaign at Spiekeroog Island (compare Fig. 1b). The concentration of $\mathrm{Mo}_{\text {diss }}$ at position OB2 and AE (not shown) decrease from 93 to $74 \mathrm{nM}$ and from 70 to $47 \mathrm{nM}$, respectively. Additionally, a transect from Langeoog Island towards Helgoland Island was carried out about $2 \mathrm{~h}$ before sampling at location CBA in the backbarrier tidal flat of Spiekeroog (Figs. 1a [black squares] and 4a). Measurements of $\mathrm{Mo}_{\text {diss }}$ reveal that the non-conservative behaviour of Mo in the Wadden Sea is seen further offshore, too. Thus, the "normal" seawater concentration of Mo is only observed at a distance of more than $25 \mathrm{~km}$ offshore the barrier islands, reflecting that this phenomenon of drastically decreasing $\mathrm{Mo}_{\text {diss }}$ concentrations covers the entire Wadden Sea system and parts of the Southern German Bight.

Subsequent sampling campaigns in the tidal inlet of Spiekeroog at position OB1 show that the concentrations of $\mathrm{Mo}_{\text {diss }}$ are still below $66 \mathrm{nM}$ in mid-August (Fig. 4b). In mid-September a level close to the seawater value is attained, which suggests that $\mathrm{Mo}_{\text {diss }}$ depletion lasts at minimum of one month. During mid-October $\mathrm{Mo}_{\text {diss }}$ increases further and exceeds the seawater level with an average value of 112 and $124 \mathrm{nM}$ when normalised to offshore salinity, respectively. In contrast, the sampling campaign in November 2005 again reveals a seawater-like level of $91 \mathrm{nM}$, which is identical with the German Bight value when normalised to salinity (Fig. 3d, Table 2).

Comparison with previous summer cruises from August 2002-2004 provides evidence about this variable behaviour of Mo in the Wadden Sea water column (Fig. 3b-d). While the data from July 2005 reveal a negative anomaly of $\mathrm{Mo}_{\text {diss }}$, the cruise in August 2002 is characterised by a distinct positive anomaly with maximum concentrations $(158 \mathrm{nM})$ at low tide. In contrast to this, data from August 2003 and 2004 reveal an almost conservative pattern with concentrations close to the seawater value.

Regarding the values of particulate $\mathrm{Mo}\left(\mathrm{Mo}_{\text {part }}\right)$ during the cruises in 2005 (Table 2) it becomes evident that along with decreasing concentrations of $\mathrm{Mo}_{\text {diss }}$ substantial enrichments of Mo are seen on aggregates in summer when compared with the other seasons. In comparison to the geogenic background (Mo/Al: 0.15; Wedepohl, 2004) aggregates are enriched on average by a factor of 20. Despite of the general enrichment, Mo/Al-ratios in July 2005 (Fig. 3e) display a variable pattern with a certain trend to higher values during high tide and more pronounced enrichments in surface samples. The comparison to other summer cruises from 2002 to 2004 (Fig. 3f-h) reveals that Mo enrichments on aggregates are only seen during phases of $\mathrm{Mo}_{\text {diss }}$ anomalies, i.e. during July 2005 and August 2002.

Certain Mo enrichments are also observed in samples of sediment traps $(<63 \mu \mathrm{m})$ from Langeoog Island between March and November 2005 (Fig. 5). The pattern of Mo/ Al-ratios reveals elevated values during July 2005, which coincides with the observed increase in Mo/Al-ratios on SPM from the water column of the Spiekeroog backbarrier tidal flat during that time (Fig. 3e).

\subsubsection{Manganese}

The Wadden Sea cruise in July 2005 is not only special regarding $\mathrm{Mo}_{\text {diss }}$ but also with respect to $\mathrm{Mn}_{\text {diss }}$. Earlier investigations on the behaviour of $\mathrm{Mn}$ in the Wadden Sea environment revealed a clear seasonal dependence with concentrations increasing by a factor of about 10 from 
a

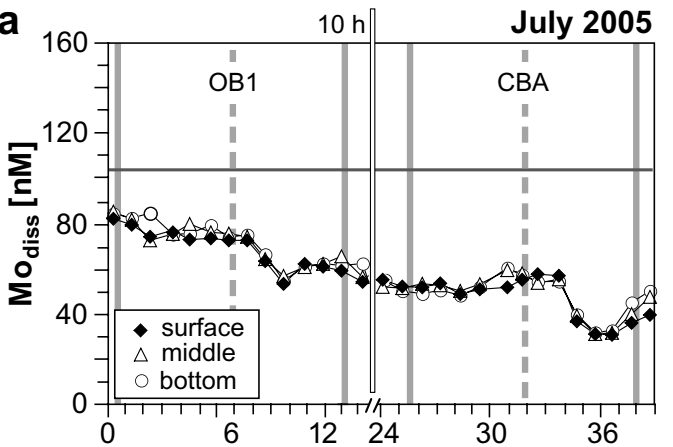

b

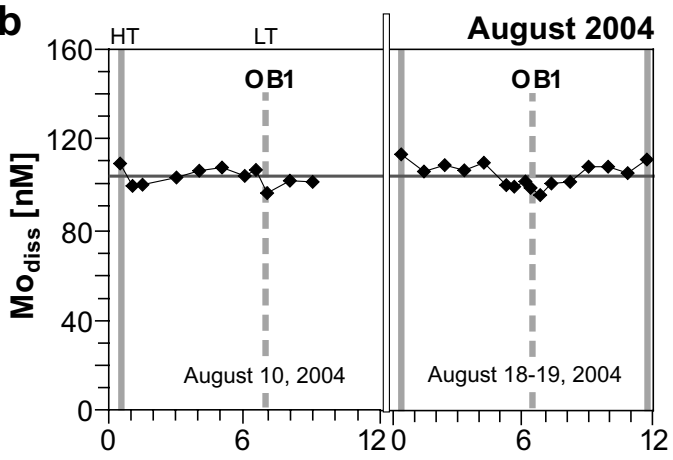

C

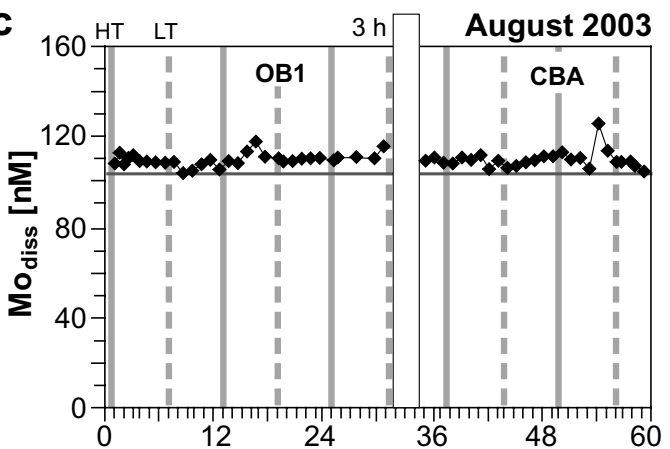

d

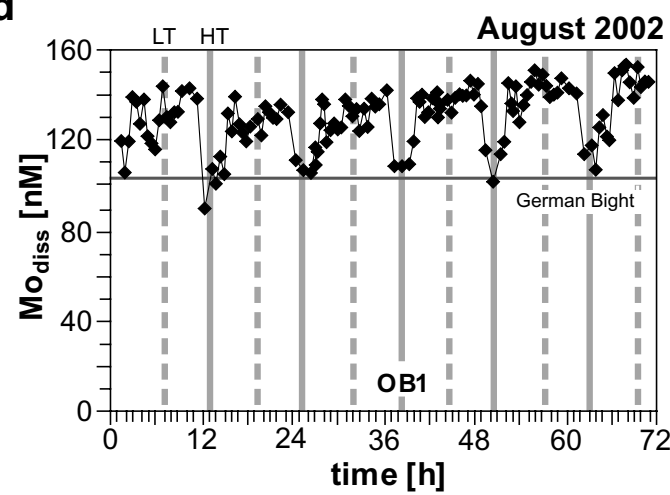

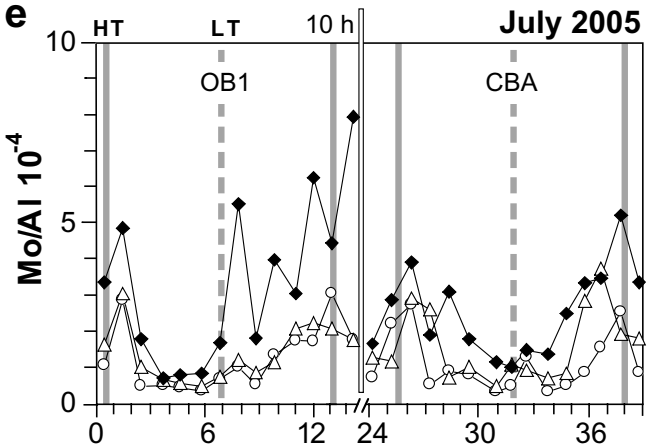
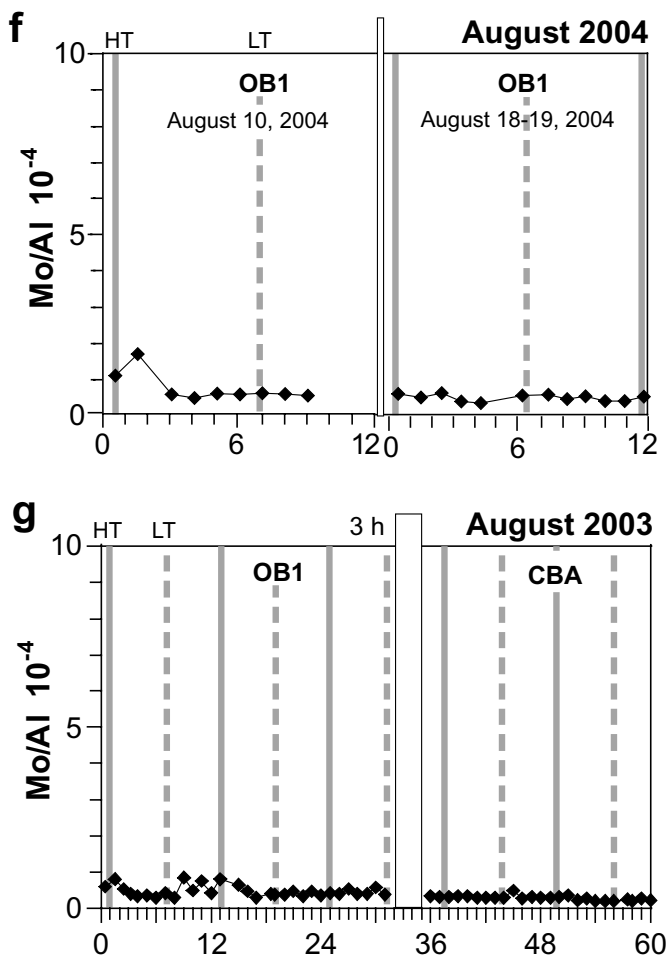

h

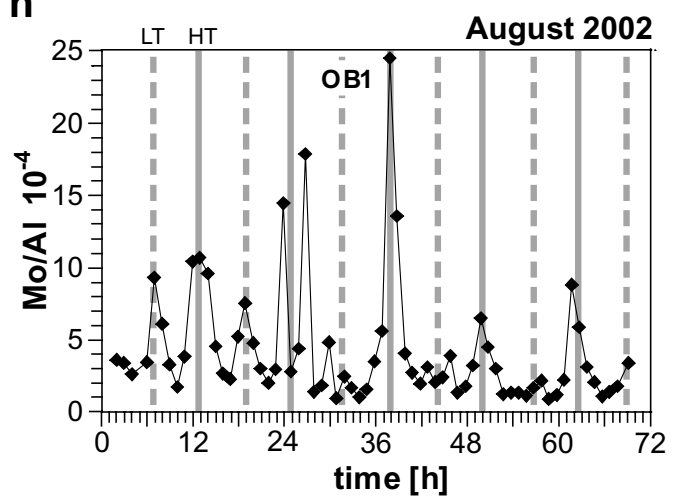

Fig. 3. Tidal patterns of dissolved Mo and Mo/Al ratios for the Wadden Sea cruises (Spiekeroog Island) from summer 2002 to 2005 . The vertical grey and dashed lines denote high tide (HT) and low tide (LT). The vertical rectangle marks a time gap between both sampling campaigns. The gray line denotes the Mo level for the offshore German Bight (data from October 2004).

winter towards summer (Dellwig et al., 2007) and vice versa. This behaviour was explained by elevated Mn concentrations in the pore fluids of the tidal flat sediments in summer due to more pronounced reducing conditions and therefore a higher release of $\mathrm{Mn}$ during ebb tide. Average concentrations of $700 \mathrm{nM}$ were reported for $\mathrm{Mn}_{\text {diss }}$ in August 2002 

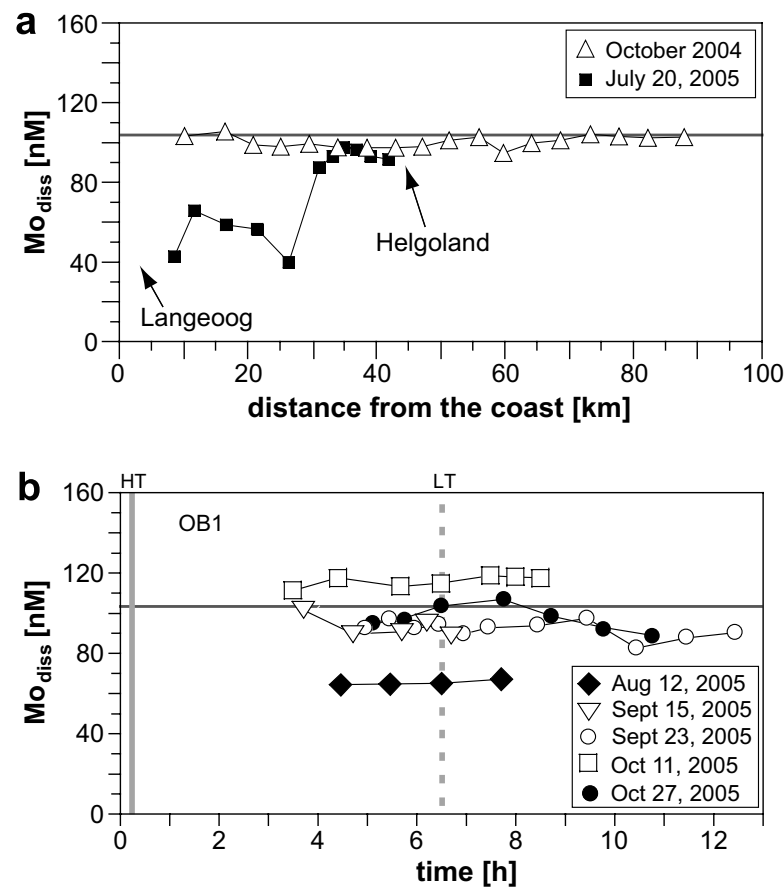

Fig. 4. Dissolved Mo of (a) transects from Langeoog Island into the German Bight, and (b) several sampling campaigns at position OB 1 in the tidal inlet of Spiekeroog Island. The grey line denotes the Mo level for the offshore German Bight (data from October 2004).

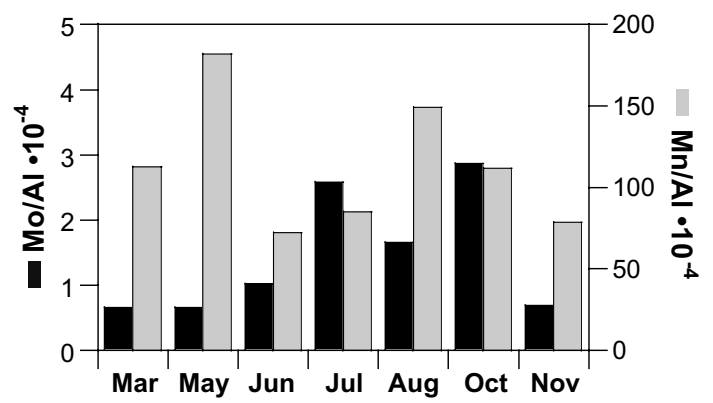

Fig. 5. $\mathrm{Mo} / \mathrm{Al}$ and $\mathrm{Mn} / \mathrm{Al}$ ratios of material $(<63 \mu \mathrm{m})$ from sediment traps of the backbarrier salt marsh of Langeoog Island from March to November 2005.

and 2003 while values in winter (February 2002, 2003: $70 \mathrm{nM}$ ), spring (May 2002, April 2003: $300 \mathrm{nM}$ ), and autumn (November 2002, 2003: $80 \mathrm{nM}$ ) were distinctly lower. During the cruises in January and April $2005 \mathrm{Mn}_{\text {diss }}$ follows this increasing trend (Fig. 6a-d, Table 2). Based on the results of cruises in 2002 and $2003, \mathrm{Mn}_{\text {diss }}$ should have been twice as high as the spring values in summer. However, a converse behaviour without any tidal dependence is observed in July 2005 , with $\mathrm{Mn}_{\text {diss }}$ values distinctly lower than in spring.

Ensuing sampling in the tidal inlet of Spiekeroog Island revealed that an increase in $\mathrm{Mn}_{\text {diss }}$ occurred somewhat later than it was observed for $\mathrm{Mo}_{\text {diss }}$ (Figs. $4 \mathrm{~b}$ and 7). In the case of $\mathrm{Mn}_{\text {diss }}$ increasing values are not observed until the end of
September. The average value of $300 \mathrm{nM}$ on September 23 is similar to previous cruises in the Wadden Sea during September (av. $280 \mathrm{nM}$, Hinrichs, 2001). Concentrations of $\mathrm{Mn}_{\text {diss }}$ continue to increase until early October and reach a maximum value of $530 \mathrm{nM}$. Two weeks later, $\mathrm{Mn}_{\text {diss }}$ dropped to values between 140 and $278 \mathrm{nM}$, which reflects the general decrease towards the November level seen in Fig. 6d.

In contrast, particulate Mn (Fig. 6e-h) shows the typical enrichments in summer when compared with the other seasons, as observed during earlier cruises as well (Dellwig et al., 2007). However, the pattern from July 2005 reveals a trend of decreasing Mn/Al-ratios parallel to increasing concentrations of $\mathrm{Mn}_{\text {diss }}$.

\subsection{Mo and Mn in the pore water of the wadden sea}

Fig. 8 shows pore water profiles of $\mathrm{Mo}_{\text {diss }}$ and $\mathrm{Mn}_{\text {diss }}$ for the sampling sites close to the low water line (location 1) and for the centre of the sand flat (location 2). At both sites (see Fig. 1b), concentrations of $\mathrm{Mo}_{\text {diss }}$ reveal elevated levels in the uppermost portion of the sediment and a strong decline at a sediment depth of about $0.5 \mathrm{~m}$. Especially at location 2 an increase in $\mathrm{Mo}_{\text {diss }}$ concentrations in the upper part of the sediment is observed from July to August. Maximum values reach $370 \mathrm{nM}$, which suggests pore waters as a significant Mo source during that time when compared with the concentration in the water column in August (av. $66 \mathrm{nM}$ ). Elevated values lasted until September, whereas in November the profile is similar to the one in July. In contrast, at location 1 , which is close to the main tidal channel, $\mathrm{Mo}_{\text {diss }}$ shows a high variability but does not significantly exceed the seawater level.

Pore water $\mathrm{Mn}_{\text {diss }}$ concentrations increase about 10 -fold from $1400 \mathrm{nM}$ to a maximum concentration of $15,000 \mathrm{nM}$ from July to August in the upper centimetres of the sediment at location 2. Extremely high values are also observed in September, especially at $0.3 \mathrm{~m}$ depth. Similar to $\mathrm{Mo}_{\text {diss }}$, location 1 reveals less pronounced enrichments in $\mathrm{Mn}_{\text {diss }}$. An exception forms the uppermost sample in September, when $\mathrm{Mn}_{\text {diss }}$ exceeds $15,000 \mathrm{nM}$. When comparing these results with the development of $\mathrm{Mn}_{\text {diss }}$ concentrations in the water column (Fig. 7) it seems evident that the pore waters represent a significant source for $\mathrm{Mn}_{\text {diss }}$ as well.

\section{DISCUSSION}

\subsection{Biological and sedimentological conditions}

The results presented so far document non-conservative behaviour of $\mathrm{Mo}_{\text {diss }}$ in the Wadden Sea during specific time intervals in summer as reflected by both, negative but also positive concentration anomalies (Fig. $3 \mathrm{a}$ and $\mathrm{d}$ ). In contrast, cruises in August 2003 and 2004 (Fig. 3b and c) displayed a more or less conservative pattern, which may reflect a transitional behaviour between extreme situations. Decreasing concentrations were also observed in the western backbarrier area of Langeoog Island (not shown) and in the adjoining near-coastal waters of the German 

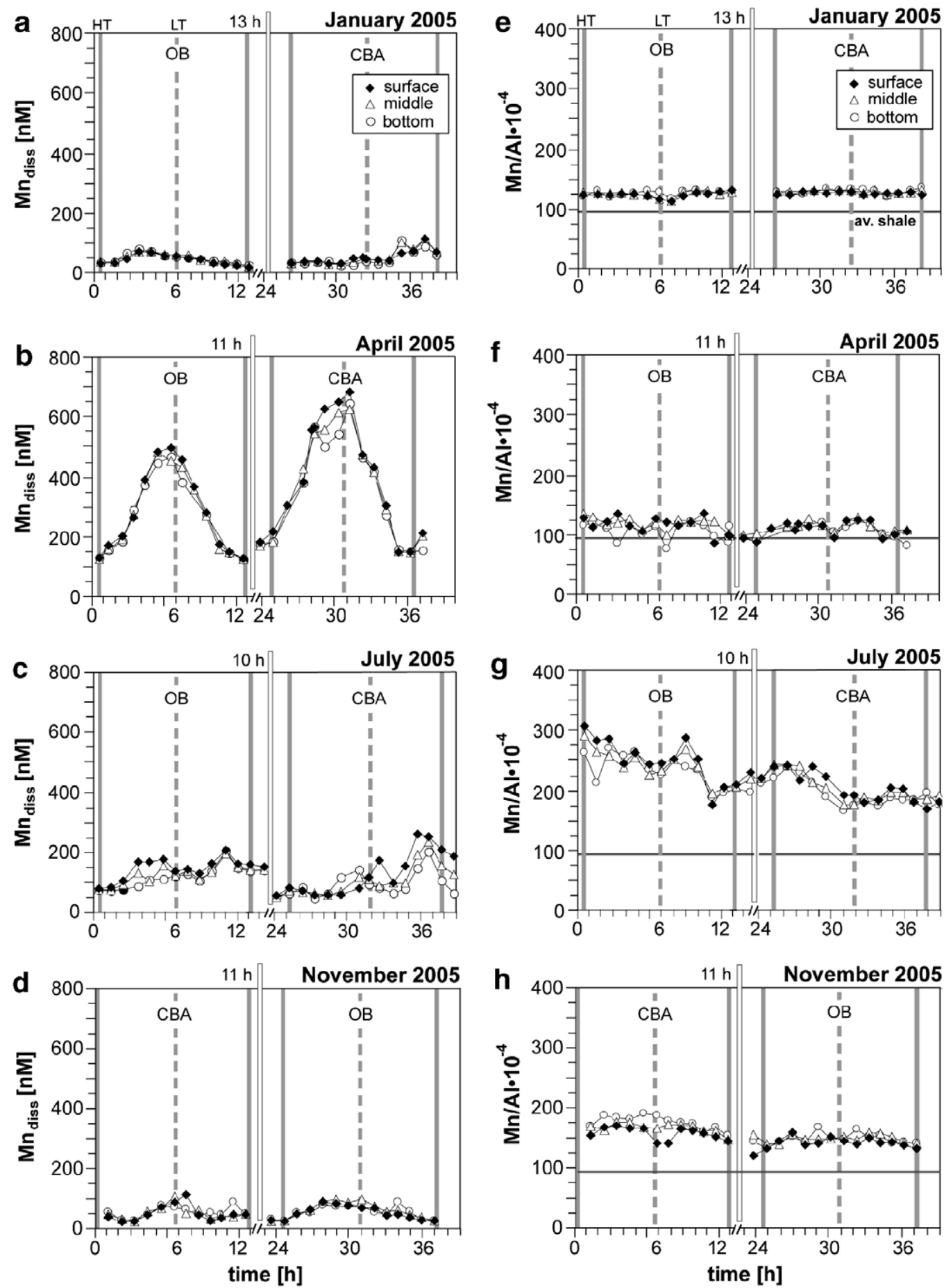

Fig. 6. Tidal patterns of dissolved Mn and Mn/Al ratios for the Wadden Sea cruises in 2005 (Spiekeroog Island). The vertical grey and dashed lines denote high tide (HT) and low tide (LT). The vertical rectangle marks a time gap between the sampling campaigns. The grey line denotes the average shale level (Wedepohl, 2004).

Bight (Fig. 4a), which gives evidence that a larger area is affected by this phenomenon.

Processes causing removal and at a later stage release of $\mathrm{Mo}_{\text {diss }}$ are necessary to explain such differing concentration signatures. For understanding the individual mechanisms causing such phenomena, it is essential to know about the distinctive characteristics of the individual summer cruises.
For that reason, the first part of the discussion deals with the biological and sedimentological aspects, while in the following chapters we will discuss the processes of removal and release of Mo.

The chlorophyll- $a$ concentrations (Table 1) point towards the occurrence of algae blooms during both cruises in April and July 2005. However, taking the percentage of 


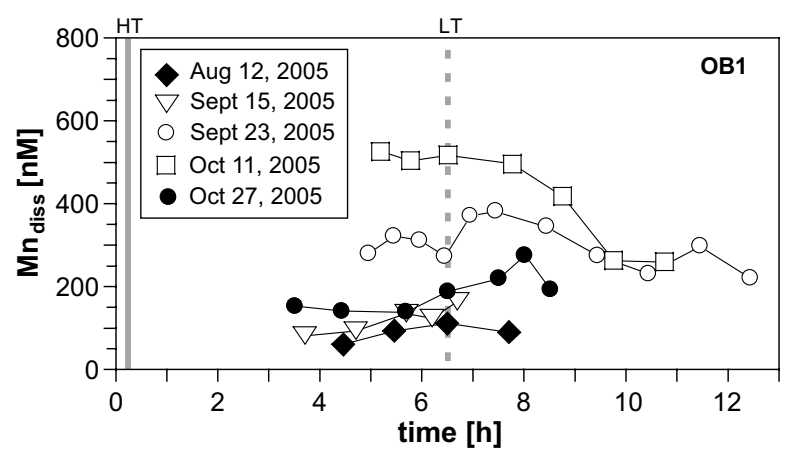

Fig. 7. Dissolved Mn from several sampling campaigns at position OB 1 in the tidal inlet of Spiekeroog Island during summer and autumn 2005. The vertical grey and dashed line denotes high tide (HT) and low tide (LT).
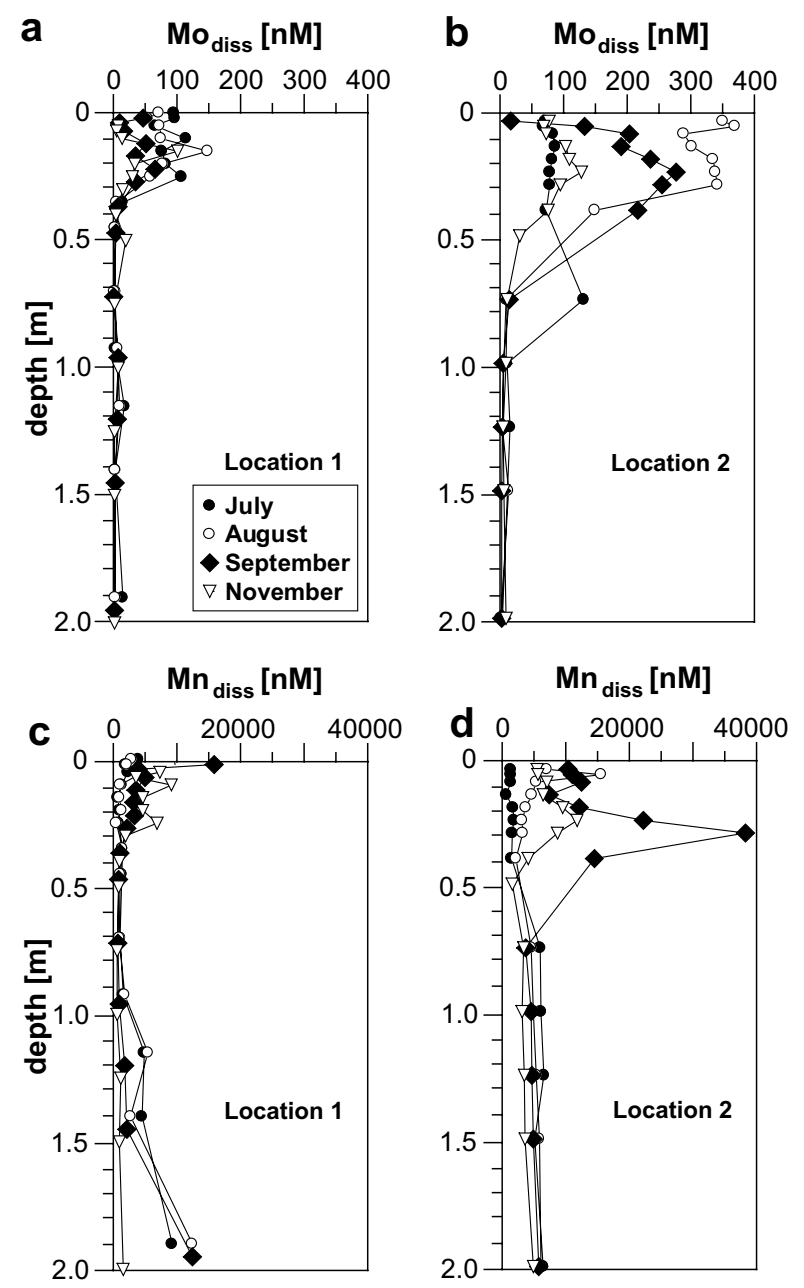

Fig. 8. Comparison of Mo and Mn pore water profiles between July and November 2005 from two locations at the Janssand tidal flat of the backbarrier area of Spiekeroog Island (compare Fig. 1b).

phaeopigments from total chlorophyll into account, which is indicative for the quality of algae material, it becomes obvious that in July 2005 the algae bloom was in a later stage, most likely in a phase of breakdown. Consequently, the onset of lyses of algae may have led to a release of elevated amounts of labile organic compounds. It is well known that such fresh and labile DOC is very rapidly degraded by bacteria (Coveney and Wetzel, 1989; Muenster, 1993). It also has the potential to form transparent exopolymer particles (TEP) from dissolved precursors. Thus we postulate, that the degradation of such algal material by free-living bacteria, which are twice as abundant in July as in April (Table 1), initiates the formation of larger aggregates in the Wadden Sea water column as recently observed by several authors (e.g. Passow, 2002; Engel et al., 2004; Chen et al., 2005; Lunau et al., 2006a; Passow and De la Rocha, 2006). A further indication of degradation and release of organic compounds is given by elevated DOC values in July when compared with the bloom in April (Table 1). Former cruises in August 2002 and 2003 showed lower DOC values as well (av. $0.21 \mathrm{mM}$; Dellwig et al., 2007) and shed light on the special situation during the cruise in July 2005.

Aggregation is documented by the comparison of ECD values between winter and summer (Table 1). Along with POC, our data suggest the occurrence of larger organic-rich aggregates in summer, whereas the winter situation is dominated by smaller inorganic particles. These larger aggregates offer favourable conditions for the formation of suboxic micro-zones, an assumption that is supported by investigations of Alldrege and Cohen (1987) and Ploug et al. (1997). The authors detected significant oxygen depletion in marine snow and laboratory-made aggregates by the use of microelectrodes. Additionally, Nielsen et al. (2005) found a distinctly higher potential for anammox inside larger aggregates when compared with smaller ones. For the formation of suboxic zones within the aggregates elevated microbial activity is necessary, a prerequisite, that is indicated by distinctly higher numbers of aggregate-associated bacteria in July 2005 (Table 1).

Aggregation during breakdown of algae blooms is of crucial importance for sedimentological and geochemical budgets of the Wadden Sea environment as the larger aggregates behave hydraulically different (Chang et al., $2006 a, b)$. This change is seen in the varying SPM loads during the cruises in 2005 (Fig. 2), which are mainly attributed to three variables: (i) the tidal state, (ii) weather conditions, and (iii) hydrological properties of aggregates. The tidal influence can be regarded in a first approximation as constant as the cruises took place during similar tidal states (spring tide at the end of the campaign). The second parameter, i.e., wind speed and wind direction, is of major importance for the hydrodynamic conditions in the Wadden Sea. For that reason it is essential that weather conditions are almost identical when comparing SPM concentrations of different cruises, which is only the case for January and July 2005 (Table 1). Nonetheless, surface SPM concentrations and the number of aggregates are considerably higher in January when compared with July, which has to be attributed to the different hydraulic properties of SPM in winter and summer (Table 1). To solve this discrepancy in SPM load between both cruises, huge amounts of larger aggregates have to be deposited on the tidal flats during summer. 
This assumption is in accordance with sedimentological investigations carried out in the backbarrier area of Spiekeroog Island by Chang et al. (2006a,b). The authors report that in summer, the surface sediment comprises a mud drape, whereas during winter the same tidal flats are dominated by sand. They also suggest that the finer particles deposited in summer are incorporated into larger flocs and aggregates and are therefore hydraulically similar to co-deposited sand.

Overall, from a biological and sedimentological view the distinctive feature in July is the breakdown of an algae bloom, which accelerated bacterial activity and growth. As a result organic matter is released by lyses and bacterial decomposition of algal material initiates the formation of larger aggregates. Huge amounts of these organic-rich aggregates are deposited on the tidal flats, thereby serving as a potential shuttle for the transfer of material and compounds from the open water column to the sediment layer. In contrast, earlier cruises in August 2002-2004 did not record this development at its initial stage. Thus, the question remains whether this special situation in July 2005 can be made responsible for the observed behaviour of Mo?

\subsection{Removal of Mo from the water column}

For the removal of $\mathrm{Mo}_{\text {diss }}$ from the water column several processes are conceivable, which comprise uptake by phytoplankton, fixation in reducing tidal flat sediments, scavenging by Mn-oxides, complexation by organic matter as well as processes in the suboxic interior of larger aggregates.

Although Mo forms an essential micro-nutrient for the nitrogen-metabolism of phytoplankton and bacteria (Howarth and Cole, 1985; Paerl et al., 1987), which can be enriched in marine cyanobacteria during nitrogen fixation (Tuit et al., 2004), culture experiments have shown that Mo uptake rates are too low $\left(0.4 \mathrm{pM} \mu \mathrm{g} \mathrm{chl}^{-1} \mathrm{~h}^{-1}\right.$; Marino et al., 2003) for explaining the $\mathrm{Mo}_{\text {diss }}$ depletion rate of $2 \mathrm{nM} \mathrm{h}^{-1}$ observed in July 2005. A further possibility may be the fixation of $\mathrm{Mo}_{\text {diss }}$ as sulphide in reducing tidal flat sediments. Again, this possibility seems to be less plausible as such process cannot explain the observed rapid loss of more than $60 \%$ of $\mathrm{Mo}_{\text {diss }}$ from the water column within $36 \mathrm{~h}$. Moreover, Mo burial in sediments prevails during the entire summer when microbial activity is high and reducing conditions in the sediments are most pronounced. Even though the settling of aggregates transfers high amounts of organic matter to the sediment, which accelerates microbial activity, our pore water profiles do not proof elevated Mo fixation in July 2005 (Fig. 8a and b).

One important mechanism may be the scavenging of $\mathrm{Mo}_{\text {diss }}$ by freshly formed $\mathrm{MnO}_{x}$ phases during bacterial oxidation of $\mathrm{Mn}_{\text {diss. }}$. Adelson et al. (2001) postulated a model for scavenging of $\mathrm{Mo}$ by $\mathrm{MnO}_{x}$ phases in order to explain Mo enrichments in sediments of Chesapeake Bay. $\mathrm{Mn}^{2+}$ refluxing from sediments is converted to particulate $\mathrm{Mn}(\mathrm{Mo}) \mathrm{O}_{x}$ during oxidation in the upper water column. Sedimentation of these particles leads to preconcentration of Mo at the sediment-water interface. Mo is liberated during reduction of Mn-oxide phases at or close to the sediment surface from where it may diffuse downward until it is fixed by organic thiols or $\mathrm{HS}^{-}$. Extremely low $\mathrm{Mn}_{\text {diss }}$ concentrations and associated enrichments in $\mathrm{Mn}_{\text {part }}$ in Wadden Sea samples from July 2005 (Fig. 6c and g) point towards intense oxidation of $\mathrm{Mn}^{2+}$. Therefore, formation of $\mathrm{Mn}(\mathrm{Mo}) \mathrm{O}_{x}$ phases might explain the depletion in $\mathrm{Mo}_{\text {diss }}$ (Fig. 3c) or vice versa the enrichment of $\mathrm{Mo}_{\text {part }}$ on SPM (Fig. 3e) observed in July 2005. Unfortunately, we do not know whether Mn-oxidising bacteria exhibit enhanced activity during an algae breakdown, which would be important information as Mn-oxidation forms a common process in the study area during summer (Dellwig et al., 2007). Comparing the Mn/Al-ratios of the summer aggregates (August 2002: 260; August 2003: 316; August 2004: 302; July 2005: 227) no unusual enrichments are observed for the cruises in July 2005 and August 2002. SPM from the latter cruises is even slightly depleted in $\mathrm{Mn}$, which contradicts a relation between $\mathrm{Mo}_{\text {diss }}$ depletion and $\mathrm{Mn}$ oxidation. In addition, unusually low values of $\mathrm{Mn}_{\text {diss }}$ in July 2005 (Fig. 6c) are most likely not due to elevated bacterial Mn oxidation but rather caused by exhaustion of the sedimentary reservoir. A finding that is supported by low $\mathrm{Mn}_{\text {diss }}$ concentrations in pore waters especially at location 2 in July 2005 (Fig. 8d).

Moreover, the patterns of $\mathrm{Mn}_{\text {diss }}$ and $\mathrm{Mn}_{\text {part }}$ display an opposite trend in July 2005. While $\mathrm{Mn}_{\text {diss }}$ tends to increase, the contents of $\mathrm{Mn}_{\text {part }}$ decline, which points towards release of Mn from SPM and argues against elevated Mn oxidation and associated Mo scavenging. The conversion of the contents of $\mathrm{Mn}_{\text {part }}$ into volume specific units reveals an average concentration of $272 \mathrm{nM}$, which is twice as high as the average concentration of $\mathrm{Mn}_{\text {diss }}(135 \mathrm{nM})$. Therefore, the gain in $\mathrm{Mn}_{\text {diss }}$ during the investigated time-period in July 2005 could be explained by release from SPM (Fig. 6c). However, release from the particulate phase would require suboxic zones in aggregates, which can be caused by an elevated number and activity of aggregate-associated bacteria, respectively (Table 1). A similar process was already postulated by Klinkhammer and McManus (2001). They explained mid-depth Mn maxima in the Columbia River estuary by reduction of $\mathrm{Mn}$ in the suboxic interior of aggregates. In addition, the authors point out the connection between $\mathrm{Mn}$ release and bacterial activity. Therefore, on the basis of our data, a relation between Mn-oxidation and Mo depletion can only hardly be deduced. Nevertheless, the possible adsorption of Mo on still existing $\mathrm{MnO}_{x}$ coatings on aggregates cannot be completely disregarded.

Despite the aforementioned reduction of $\mathrm{MnO}_{\mathrm{x}}$ phases, oxygen-depleted micro-zones in aggregates may be the loci for $\mathrm{Mo}_{\text {diss }}$ reduction and removal from the water column as well. In view of the $x y$-plots shown in Fig. 9 a relationship between bacterial abundance on aggregates and $\mathrm{Mo}_{\text {diss }}$ and $\mathrm{Mn}_{\text {diss }}$ concentrations becomes obvious. Thus, we postulate that increasing abundance and activity of bacteria on organic-rich aggregates produces oxygen-depleted microzones, which enable fixation of Mo and release of Mn from the aggregates. Unfortunately, our data do not provide information about the particular mechanism of Mo fixation. In addition to chemical processes, reduction by bacteria is also conceivable as shown by Ghani et al. (1993). The same is true for $\mathrm{Mn}$, either bacteria may start to reduce 

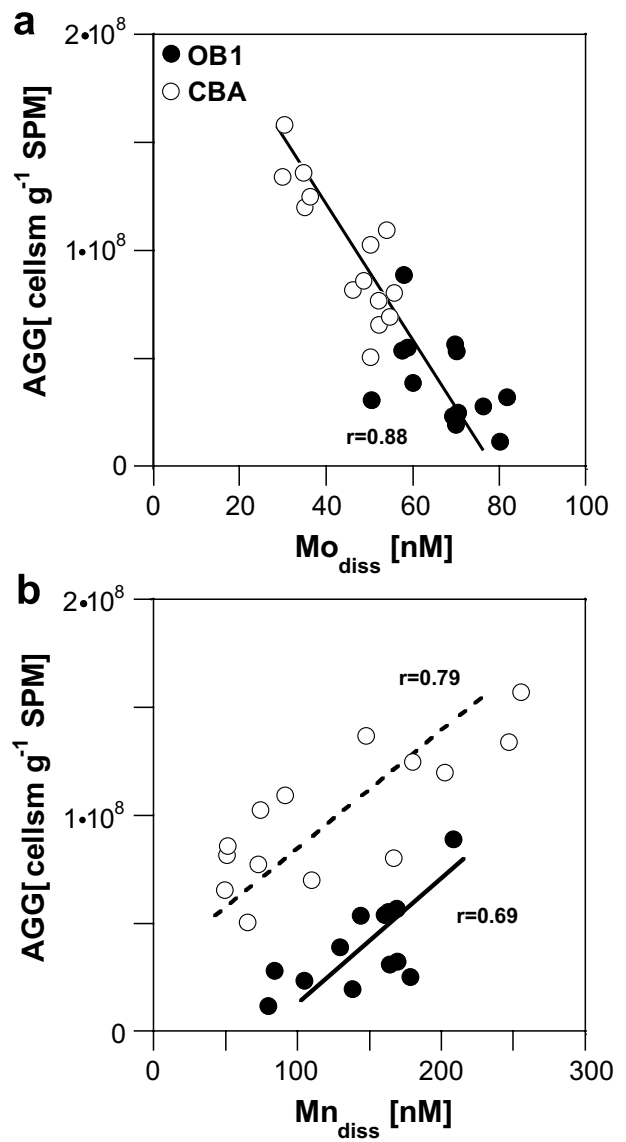

Fig. 9. Correlation diagrams of dissolved Mn and Mo versus aggregate-associated bacteria (normalized to SPM) for surface water samples from the backbarrier area of Spiekeroog Island in July 2005.

$\mathrm{Mn}_{\text {part }}$ directly, or $\mathrm{Mn}$ may be reduced chemically in suboxic zones.

Besides this direct fixation of Mo in micro-zones, fresh algal organic matter and certain humic substances are also capable to capture $\mathrm{MoO}_{4}{ }^{2-}$ from solution (Szilagyi, 1967; Bertine, 1972; Volkov and Formina, 1974; Nissenbaum and Swaine, 1976; Disnar, 1981; Brumsack and Gieskes, 1983; Alberic et al., 2000), particularly when the organic matter is sulphurised (Tribovillard et al., 2004). An increase in organic matter content of SPM is evident from POC data, which show elevated values in spring and especially during summer (max, 28.7\%; Table 1). Additionally, Bertine (1972) report increased Mo scavenging and/or reduction of Mo by organic acids with decreasing $\mathrm{pH}$. This should be the case in the suboxic interior of aggregates as shown by Alldrege and Cohen (1987) and Ploug et al. (1997).

Both processes, reduction in oxygen-depleted zones and scavenging by organic matter are strongly coupled to biological activity. The release/bacterial degradation of fresh algal organic matter especially during breakdown of blooms causes aggregation, and is therefore limited to a specific time interval. Only such processes are able to explain the abrupt decrease in $\mathrm{Mo}_{\text {diss }}$, whereas the processes mentioned before are not limited to a certain time interval or event. For instance, fixation of Mo in sediments as well as scavenging of Mo by $\mathrm{MnO}_{x}$ should occur during the entire summer.

\subsection{Fate of Mo on aggregates}

As seen in Figs. 3a and e, the rapid loss of $\mathrm{Mo}_{\text {diss }}$ in July 2005 corresponds with substantial enrichments of $\mathrm{Mo}_{\text {part }}$ on aggregates. However, it is of crucial importance whether the Mo enrichment on SPM is balanced by the loss in $\mathrm{Mo}_{\text {diss. }}$. This requires the direct comparison of dissolved and particulate metal concentrations per volume unit. For that reason, we calculated excess element concentrations, which reflect the amount of Mo added to SPM in addition to the geogenic background. This excess fraction is calculated according to the following equations (average shale data from Wedepohl, 2004):

$\mathrm{Mo}_{\text {background }}=(\mathrm{Mo} / \mathrm{Al})_{\text {av.shale }} \times \mathrm{Al}_{\text {sample }}$

$\mathrm{Mo}_{\text {excess }}=\mathrm{Mo}_{\text {sample }}-\mathrm{Mo}_{\text {background }}$

The conversion of $\mathrm{Mo}_{\text {excess }}$ into volume specific Mo concentrations $\left(\mathrm{Mo}_{\mathrm{xs}}\right)$ is done by multiplication with SPM concentrations. The resulting concentrations of $\mathrm{Mo}_{\mathrm{xs}}$ indicate that the particulate phase, even though highly enriched in Mo, cannot explain the observed loss in $\mathrm{Mo}_{\text {diss }}$ in the water column. The average value of $\mathrm{Mo}_{\mathrm{xs}}(2.5 \mathrm{nM})$ only explains $6 \%$ of the loss in $\mathrm{Mo}_{\text {diss. }}$. In our view, this discrepancy can only be explained by the rapid sedimentation of Mo-rich particles following particle aggregation during breakdown of an algae bloom (see Section 5.1).

According to M. Beck (pers. comm.) deposited aggregates formed a widespread fluffy layer on the tidal flat sediments next to the pore water sampling site 2 . Unfortunately, this fluffy material is not available for geochemical analyses. However, the geochemical composition of these aggregates is most likely reflected in sediment trap samples collected in the backbarrier salt marsh of Langeoog Island (Fig. 5). This material shows enrichments in Mo from summer to early autumn. Furthermore, the pattern of $\mathrm{Mn}$ is in accordance with an alternating dominance of Mn-oxidation and Mn-reduction. Mn-oxidation prevails in spring and late summer, whereas in June and July, when aggregation along with the development of suboxic micro-zones in aggregates becomes more important, decreasing values are due to intense Mn-reduction.

In our view it is rather likely that the deposition of such aggregates may explain the discrepancy in the balance between $\mathrm{Mo}_{\text {diss }}$ loss and the apparent lack of particulate $\mathrm{Mo}_{\mathrm{xs}}$ to compensate for this loss. Thus, we propose that large amounts of $\mathrm{Mo}_{\text {diss }}$ are removed from the water column owing to deposition of Mo-rich and still Mn-rich aggregates during breakdown of an algae bloom in early summer. Additionally, with the transfer of Mo and Mn into the upper sediment layer by settling aggregates organic matter is added to the sediment, which favours microbial activity and therefore the decomposition of buried aggregates.

\subsection{Fate of Mo in the sediments: implications from the pore water}

Aggregates formed in the open water column were deposited on the sand flat Janssand in July 2005 especially 
at location 2 (Fig. 1b), leading to the accumulation of a fine layer of Mo- and still Mn-rich particulate matter at the sediment surface. Although still under debate, adherence of deposited aggregates on the tidal flats may be favoured by release of extracellular polymeric substances (EPS) from benthic diatoms and cyanobacteria. As EPS compounds exhibit stickiness, they are presumably increasing the erosion threshold (Stal, 2003). This material is supposed to be subsequently incorporated into subsurface layers of the sediment. The transport of particulate matter into permeable sandy sediment by boundary flows, which interact with sea bed topography, for example sediment wave ripples, has often been described and modelled (Huettel and Rusch, 2000; Rusch and Huettel, 2000; Precht and Huettel, 2003; de Beer et al., 2005). While these aggregates are incorporated into the sediment, $\mathrm{Mn}$ and $\mathrm{Mo}$ are released once the aggregates experience reducing conditions in slightly deeper sections of the sediment (Duinker et al., 1974; Bur- dige, 1993). Stabilisation of Mo in the pore water is probably assured by complexation with dissolved organic matter (Brumsack and Gieskes, 1983). The microbially induced release of both metals, which is caused by decomposition of organic aggregates, explains the observed increases in $\mathrm{Mo}_{\text {diss }}$ and $\mathrm{Mn}_{\text {diss }}$ in the pore water at location 2 from July to September 2005 (Fig. 8b and d) reasonably well.

Due to tidal dynamics, exchange processes occur between the surface sediment pore waters and the open water column (Huettel et al., 1998). This process contributes $\mathrm{Mo}_{\text {diss }}$ and $\mathrm{Mn}_{\text {diss }}$ to the water column as seen in increasing concentrations in August and September 2005 (Figs. 4b and 7). The same phenomenon of $\mathrm{Mo}_{\text {diss }}$ release from pore water may explain the positive anomaly in $\mathrm{Mo}_{\text {diss }}$ at low tide observed in August 2002 (Fig. 5a). The hypothesis of Mo release from pore water is supported by observations of Dalai et al. (2005) who explained excess concentrations of Mo at salinity $>5$ in the Chao Phraya Estuary by release

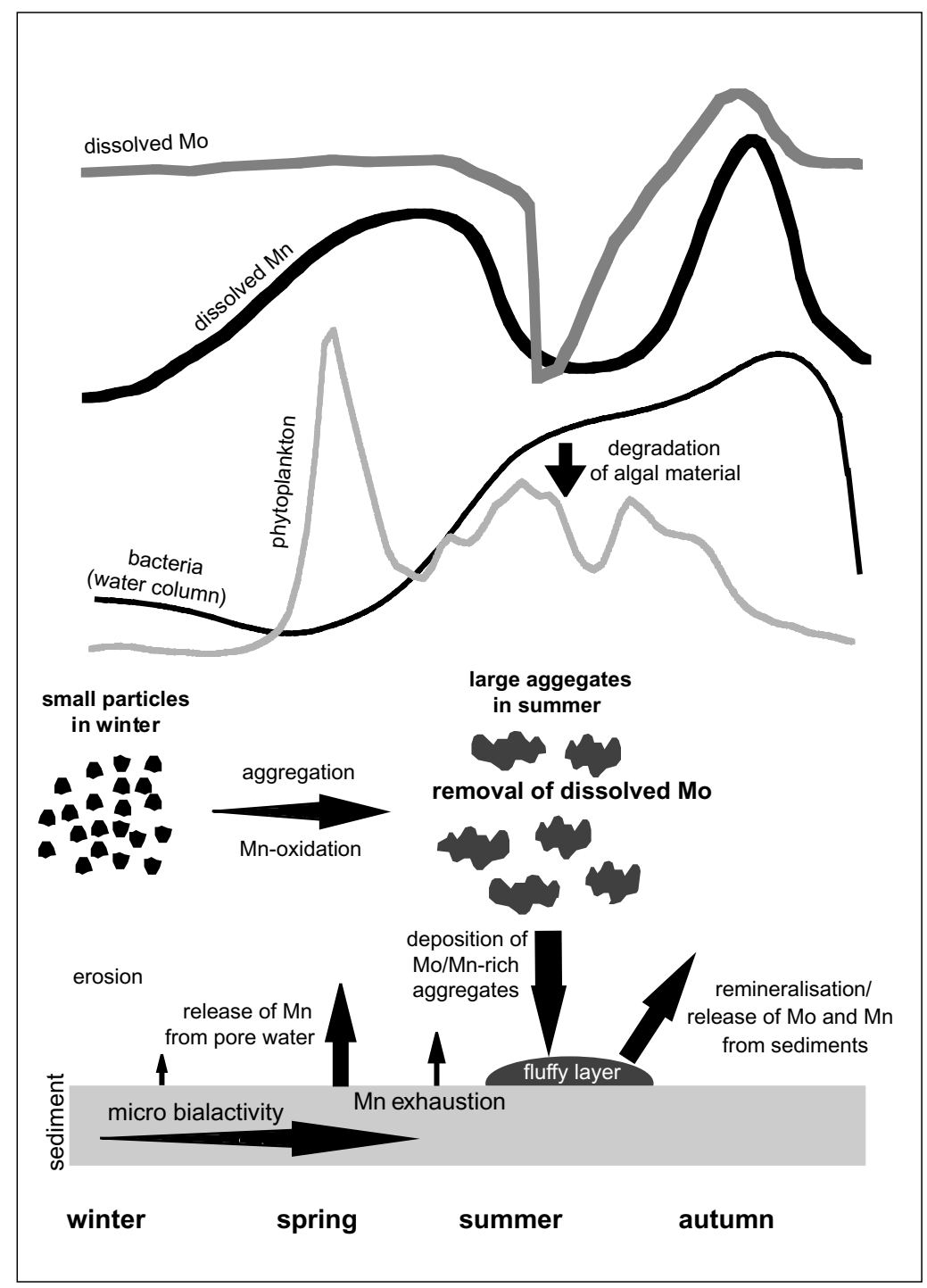

Fig. 10. Illustration of the postulated model for non-conservative behaviour of Mo in coastal waters, which is based on the tight coupling between geochemical, biological, and sedimentological processes. Phytoplankton pattern bases on model results by Kohlmeier (2004). 
from pore waters and changing redox conditions. Furthermore, experiments with in situ benthic flux chambers carried out by Morford et al. (2007) revealed substantial release of Mo from Boston Harbor sediments.

In the case of Mn, settling of Mn-rich aggregates forms an important process for the Mn budget of the Wadden Sea environment. The comparison of $\mathrm{Mn}_{\text {diss }}$ between July 2005 and April 2005 (Table 2) reveals an unusually low level during the summer cruise. In addition to intense Mn-oxidation in the water column, this observation seems to be caused to a certain degree by exhaustion of the tidal flat sediments of reactive $\mathrm{Mn}$. This assumption is in accordance with the findings of Dellwig et al. (2007) who showed that during spring and especially summer, the Mn budget of the Wadden Sea water column is almost completely controlled by release from pore waters. Therefore, deposition of aggregates and concomitant $\mathrm{Mn}$ reduction form a recharge mechanism explaining the increasing $M_{\text {diss }}$ values observed in September and early October 2005 (Fig. 7).

\section{SUMMARY AND CONCLUDING REMARKS}

Non-conservative behaviour of dissolved Mo was observed in the Wadden Sea of NW Germany, i.e., negative but also positive anomalies. In the backbarrier tidal flat of Spiekeroog Island concentrations of dissolved Mo declined from a seawater-like level to a minimum value of $30 \mathrm{nM}$ within $36 \mathrm{~h}$ during July 2005. This phenomenon was also observed in the adjoining backbarrier tidal flat of Langeoog Island and in near-coastal water masses about $25 \mathrm{~km}$ offshore. Further measurements provide evidence that this depletion, which is accompanied by significant Mo enrichments on SPM, lasted for at minimum 4 weeks. In contrast, elevated $\mathrm{Mo}_{\text {diss }}$ values (maximum $158 \mathrm{nM}$ ) were observed in August 2002. During this period $\mathrm{Mo}_{\text {diss }}$ displayed a tidal cyclicity with maximum concentrations during low tide, which points towards the tidal flat sediments as the dominant source.

This non-conservative behaviour of Mo can only be explained by the tight coupling of biological, sedimentologi$\mathrm{cal}$, and geochemical processes, as summarised in the sketch shown in Fig. 10. The controlling forces are algae blooms and the associated growth of bacteria. While the algae spring bloom does not influence the total number of bacteria, this does not seem to be the case for the algae bloom in summer, when bacterial activity and number increased significantly. Bacterial decomposition of algae releases organic compounds, which promote aggregation of suspended mineral particles. $\mathrm{MoO}_{4}{ }^{2-}$ seems to be reduced in oxygen-depleted zones of larger aggregates and/or is "scavenged" by freshly formed organic matter resulting in prominent $\mathrm{Mo}_{\text {part }}$ enrichment. A relation between the depletion of Mo and the formation of $\mathrm{MnO}_{x}$ phases is not indicated by our data.

$\mathrm{Mn}_{\text {diss }}$ concentrations are unusually low during this specific time period, which is either caused by exhaustion of the tidal flat sedimentary pool in reactive $\mathrm{Mn}$ or Mn-oxidation in the water column, which also diminishes the concentration in $\mathrm{Mn}_{\mathrm{diss}}$ and leads to Mn enrichments on aggregates.

Huge amounts of larger aggregates and associated Mo and $\mathrm{Mn}$ are deposited on the tidal flats, leading to a deple- tion of these elements in the water column. Microbial decomposition of shallowly buried aggregates leads to release of Mo and Mn from the sediments and replenishes the trace metal pool in the water column, as seen in increasing trace metal concentrations in the pore water pool in late summer as well as subsequently in the water column.

In addition to the transfer of trace metals into the sediments via deposition of aggregates, this process also leads to a sudden deposition of huge amounts of organic matter, which enhances microbial activity in the sediments.

The postulated coupling of biological, sedimentological, and geochemical processes may also be of significant relevance for Mo and possibly other trace metal enrichments in TOC-rich marine deposits. Thus, the transfer of Mo to the sediments via settling aggregates will concentrate Mo at the sediment/water interface from where it may diffuse into the deeper anoxic zone where it may finally be fixed as a sulphide.

\section{ACKNOWLEDGMENTS}

The authors thank the crews of the research vessels RV Senckenberg and RV Heincke for active support during the cruises. Maik Grunwald, Alexander "Josi" Josefowicz, Sibylle Kölsch, and Laura Wehrmann are thanked for their great assistance during several sampling campaigns. We thank Holger Freund and Jan Barkowski (ICBM, Marine Station) for making material from the sediment traps available. Further thanks are due to Andrea Lübben and Frank Terjung (Marine Physics, University of Oldenburg) for providing several salinity and water temperature data of the cruises with RV Senckenberg and RV Heincke. Two anonymous reviewers and Tim Shaw are thanked for their helpful and constructive comments. This study was funded by the Deutsche Forschungsgemeinschaft (DFG) through Grants BR 775/14-1/2 and forms part of the Research Group "BioGeoChemistry of Tidal Flats".

\section{REFERENCES}

Adelson J. M., Helz G. R., and Miller C. V. (2001) Reconstructing the rise of recent coastal anoxia; molybdenum in Chesapeake Bay sediments. Geochim. Cosmochim. Acta 65(2), 237-252.

Alberic P., Viollier E., Jezequel D., Grosbois C., and Michard G. (2000) Interactions between trace elements and dissolved organic matter in the stagnant anoxic deep layer of a meromictic lake. Limnol. Oceanogr. 45(5), 1088-1096.

Alldrege A. L., and Cohen Y. (1987) Can microscale chemical patches persist in the sea? Microelectrode study of marine snow, Fecal pellets. Science 235, 689-691.

Beck M., Dellwig O., Kolditz K.M., Liebezeit G., and Brumsack H. -J. (accepted for publication) In situ pore water sampling in deep intertidal flat sediments. Limnol. Oceanogr.: Methods.

Berrang P. G., and Grill E. V. (1974) The effect of manganese oxide scavenging on molybdenum in Saanich Inlet, British Columbia. Mar. Chem. 2, 125-148.

Bertine K. K. (1972) The deposition of molybdenum in anoxic waters. Mar. Chem. 1, 43-53.

Brumsack H. J., and Gieskes J. M. (1983) Interstitial water tracemetal chemistry of laminated sediments from the Gulf of California, Mexico. Mar. Chem. 14(1), 89-106.

Brumsack H.-J. (2006) Trace metal content of recent organic carbon-rich sediments: implications for cretaceous black shale formation. Palaeogr., Palaeoclim., Palaeoecol. 232, 344-361. 
Burdige D. J. (1993) The biogeochemistry of manganese and iron reduction in marine-sediments. Earth-Sci. Rev. 35(3), 249-284.

Chang T. S., Bartholomä A., and Flemming B. W. (2006a) Seasonal dynamics of fine-grained sediments in a back-barrier tidal basin of the German Wadden Sea (Southern North Sea). J. Coast. Res. 22(2), 328-338.

Chang T. S., Jördel O., Flemming B., and Bartholomä A. (2006b) The role of particle aggregation/disaggregation in muddy sediment dynamics and seasonal sediment turnover in a backbarrier tidal basin, East Frisian Wadden Sea, southern North Sea. Mar. Geol. 235, 49-61.

Chen M. S., Wartel S., and Temmerman S. (2005) Seasonal variation of floc characteristics on tidal flats, the Scheldt estuary. Hydrobiology 540, 181-195.

Collier R. W. (1985) Molybdenum in the Northeast Pacific-Ocean. Limnol. Oceanogr. 30(6), 1351-1354.

Coveney M. F., and Wetzel R. G. (1989) Bacterial metabolism of algal extracelluar carbon. Hydrobiologia 173, 141-149.

de Beer D., Wenzhöfer F., Ferdelman T. G., Boehme S. E., Huettel M., van Beusekom J. E. E., Böttcher M. E., Musat N., and Dubilier N. (2005) Transport and mineralization rates in North Sea sandy intertidal sediments, Sylt-Romo Basin, Wadden Sea. Limnol. Oceanogr. 50(1), 113-127.

Dalai T. K., Nishimura K., and Nozaki Y. (2005) Geochemistry of molybdenum in the Chao Phraya River estuary, Thailand: role of suboxic diagenesis and porewater transport. Chem. Geol. 218(3-4), 189-202.

Dellwig O., Bosselmann K., Kölsch S., Hentscher M., Hinrichs J., Böttche R. M. E., Reuter R., and Brumsack H.-J. (2007) Sources and fate of manganese in a tidal basin of the German Wadden Sea. J. Sea Res. 57, 1-18.

Disnar J.-R. (1981) Etude expérimentale de la fixation de métaux par un matériau sédimentaire actuel d'origine algaire- II. Fixation "in vitro" de $\mathrm{UO}_{3}{ }^{-}, \mathrm{Cu}^{2+}, \mathrm{Ni}^{2+}, \mathrm{Zn}^{2+}, \mathrm{Pb}^{2+}, \mathrm{Co}^{2+}$, $\mathrm{Mn}^{2+}$, ainsi quede $\mathrm{VO}_{3}{ }^{-}, \mathrm{MoO}_{4}{ }^{2-}$ et $\mathrm{GeO}_{3}{ }^{3-}$. Geochim. Cosmochim. Acta 10, 2152-2161.

Duinker J. C., van Eck G. T. M., and Nolting R. F. (1974) On the behaviour of copper, zinc, iron and manganese, and evidence for mobilization processes in the Dutch Wadden Sea. Netherlands J. Sea Res. 8(2-3), 214-239.

Engel A., Thoms S., Riebesell U., Rochelle-Newall E., and Zondervan I. (2004) Polysaccharide aggregation as a potential sink of marine dissolved organic carbon. Nature 428(6986), 929-932.

Fogg G. E., and Wolfe M. (1954) Nitrogen metabolization of bluegreen algae. Symp. Soc. Gen. Microbiol. 4, 99-125.

Fogg G. E. (1962) Extracellular products. In Physiology and Biogeochemistry of Algae (ed. R. A. Baldwin). Academic Press Inc, New York, pp. 475-489.

Ghani B., Masataka T., Hisham N. Z., Kishimoto N., Ismail A. K. M., Tano T., and Sugio T. (1993) Isolation and characterization of a $\mathrm{Mo}^{6+}$-reducing bacterium. App. Environ. Microbiol. 59(4), $1176-1180$.

Head P. C., and Burton J. D. (1970) Molybdenum in some ocean and estuarine waters. J. Mar. Biol. Assoc. UK 50, 439-448.

Heinrichs H., Brumsack H.-J., Loftfield N., and König N. (1986) Verbessertes Druckaufschlußsystem für biologische und anorganische Materialien. Z. Pflanzenernährung Bodenkunde 149, 350-353.

Hinrichs J. (2001) Geochemical tracers in the deep-sea and the North Sea. PhD Thesis. University of Oldenburg.

Howarth R. W., and Cole J. J. (1985) Molybdenum availability, nitrogen limitation, and phytoplankton growth in naturalwaters. Science 229(4714), 653-655.

Huettel M., Ziebis W., Forster S., and Luther, III, G. W. (1998) Advective transport affecting metal and nutrient distributions and interfacial fluxes in permeable sediments. Geochim. Cosmochim. Acta 62(4), 613-631.

Huettel M., and Rusch A. (2000) Transport and degradation of phytoplankton in permeable sediment. Limnol. Oceanogr. 45(3), 534-549.

Klinkhammer G. P., and McManus J. (2001) Dissolved manganese in the Columbia River estuary: production in the water column. Geochim. Cosmochim. Acta 65, 2835-2841.

Kohlmeier C. (2004) Modellierung des Spiekerooger Rückseitenwatts mit einem gekoppelten Euler-Lagrange-Modell auf der Basis von ERSEM. PhD Thesis, University of Oldenburg, Germany, 224p.

Lunau M., Sommer A., Lemke A., Grossart H.-P., and Simon M. (2004) A new sampling device for microaggregates in turbid aquatic systems. Limnol. Oceanogr.: Methods 2, 387-397.

Lunau M., Lemke A., Dellwig O., and Simon M. (2006a) Physical and biogeochemical controls of microaggregate dynamics in a tidally affected coastal ecosystem. Limnol. Oceanogr. 51(2), 847-859.

Lunau M., Lemke A., Walther K., Martens-Habbena W., and Simon M. (2006b) An improved method for counting bacteria from sediments and turbid environments by epifluorescence microscopy. Environ. Microbiol. 7, 961-968.

Marino R., Howarth R. W., Chan F., Cole J. J., and Likens G. E. (2003) Sulfate inhibition of molybdenum-dependent nitrogen fixation by planktonic cyanobacteria under seawater conditions: a non-reversible effect. Hydrobiologia 500(1-3), 277-293.

Mendel R. R. (2005) Molybdenum: biological activity and metabolism. Dalton Trans., 3404-3409.

Morris A. W. (1975) Dissolved molybdenum and vanadium in Northeast Atlantic Ocean. Deep-Sea Res. 22(1), 49-54.

Morford J., Martin W. R., Kalnejais L. H., Francois R., Bothner M., and Karle I.-M. (2007) Insights on geochemical cycling of $\mathrm{U}, \mathrm{Re}$ and Mo from seasonal sampling in Boston Habor, Massachusetts, USA. Geochim. Cosmochim. Acta 71, 895-917.

Muenster U. (1993) Concentrations and fluxes of organic carbon substrates in the aquatic environment. Antonie Van Leeuwenhoek 63, 243-274.

Nielsen M., Bollmann A., Sliekers O., Jetten M., Schmid M., Strous M., Schmidt I., Larsen L. H., Nielsen L. P., and Revsbech N. P. (2005) Kinetics, diffusional limitation and microscale distribution of chemistry and organisms in a CANON reactor. FEMS Microbiol. Ecol. 51(2), 247-256.

Nissenbaum A., and Swaine D. J. (1976) Organic matter-metal interaction in recent sediments, the role of humic substances. Geochim. Cosmochim. Acta 40, 809-816.

Paerl H. W., Crocke R. K. M., and Prufert L. E. (1987) Limitation of N-2 fixation in coastal marine waters-relative importance of molybdenum, iron, phosphorus, and organic-matter availability. Limnol. Oceanogr. 32(3), 525-536.

Passow U. (2002) Transparent exopolymer particles (TEP) in aquatic environments. Progress Oceanogr. 55(3-4), 287-333.

Passow U., and De la Rocha C. L. (2006) Accumulation of mineral ballast on organic aggregates. Global Biogeochem. Cycles 20(1).

Ploug H., Kühl M., Buchholz-Cleven B., and Jørgensen B. B. (1997) Anoxic aggregates - an ephemeral phenomenon in the pelagic environment? Aquat. Microb. Ecol. 13, 285-294.

Precht E., and Huettel M. (2003) Advective pore-water exchange driven by surface gravity waves and its ecological implications. Limnol. Oceanogr. 48(4), 1674-1684.

Robson R. L., Eady R. R., Richardson T. H., Miller R. W., Hawkins M., and Postgate J. R. (1986) The alternative nitrogenase of Azotobacter-Chroococcum is a vanadium enzyme. Nature 322(6077), 388-390.

Rodushkin I., and Ruth T. (1997) Determination of trace metals in estuarine and sea-water reference materials by high resolution 
inductively coupled plasma mass spectrometry. J. Anal. Atomic Spectrom. 12(10), 1181-1185.

Rusch A., and Huettel M. (2000) Advective particle transport into permeable sediments - evidence from experiments in an intertidal sandflat. Limnol. Oceanogr. 45(3), 525-533.

Stal L. J. (2003) Microphytobenthos, their extracellular polymeric substances, and the morphogenesis of intertidal sediments. Geomicrobiol. J. 20(5), 463-478.

Streif H. (1990) Das ostfriesische Küstengebiet. Gebrüder Borntaeger, Berlin.

Szalay A., and Szilagyi M. (1967) Association of vanadium with humic acids. Geochim. Cosmochim. Acta 31(1), 1-6.

Szilagyi M. (1967) Sorption of molybdenum by humus preparations. Geochem. Int. 4, 1165-1167.

Tribovillard N., Riboulleau A., Lyons T., and Baudin F. O. (2004) Enhanced trapping of molybdenum by sulfurized marine organic matter of marine origin in Mesozoic limestones and shales. Chem. Geol. 213(4), 385-401.

Tuit C. B., and Ravizza G. (2003) The marine distribution of molybdenum. Geochim. Cosmochim. Acta 67(18), A495, Suppl. 1.

Tuit C., Waterbury J., and Ravizzaz G. (2004) Diel variation of molybdenum and iron in marine diazotrophic cyanobacteria. Limnol. Oceanogr. 49(4), 978-990.
UNESCO (1981) The Practical Salinity Scale 1978 and the International Equation of State of Seawater 1980. Tenth Report on the Joint Panel on Oceanographic Tables and Standards. UNESCO Technical Paper in Marine Science 36, UNESCO, Paris.

Volkov I. I., and Formina L. S. (1974) Influence of organic material and processes of sulphide formation on distribution of some trace elements in deep-water sediment of Black Sea. AAPG Memoir 20, 457-476.

von Tuempling W., and Friedrich G. (1999) Biologische Gewässeruntersuchung. Jena; Stuttgart; Lübeck; Ulm, G. Fischer.

Wedepohl K.H. (2004) The composition of earth's upper crust, natural cycles of elements, natural resources. In Elements and their Compounds in the Environment (eds. E. Merian, M. Anke, M. Ihnat and M. Stoeppler), 2nd ed. Wiley-VCH, pp. 3-17.

Yamazaki H., and Gohda S. (1990) Distribution of dissolved molybdenum in the Seto Inland Sea, the Japan Sea, the Bering Sea and the Northwest Pacific-Ocean. Geochem. J. 24(4), 273281. 